\title{
SAINTS, PAGANS, AND THE WONDERS OF THE EAST: THE MEDIEVAL IMAGINARY AND ITS MANUSCRIPT CONTEXTS
}

\author{
BY JOHN ELDEVIK
}

\begin{abstract}
Studies about Christian perceptions of Islam and other non-Christian cultures in the Middle Ages in recent years have tended to focus on individual authors and their works. New research in the field of manuscript philology, particularly its focus on the idea of the "whole book," however, suggests some new interpretive vistas that can sharpen our understanding of how medieval readers engaged with, and responded to, texts about the non-Christian Other. This article takes as its subject a twelfthcentury miscellany manuscript from the Westfalian monastery of Grafschaft that constitutes a remarkable dossier of hagiographical and exegetical texts relating to Muslims, pagans, and holy war. This codex, Darmstadt Universitäts- und Landesbibliothek, Cod. 749, offers a window onto how works dealing with these subjects were read not only on their own terms, but in dynamic relationship to one another. Focusing on the associative resonances between the different works in a single manuscript allows us to understand how one monastic community in northern Germany sought to place the twelfth-century Crusades in a broader historical and theological context. The results of such an approach complicate the traditional Christian-Muslim binary we usually encounter in studies of Crusading or medieval views of non-Christians, underscoring how one community of medieval readers thought about the problem of religious conflict in several temporal, geographic, and conceptual dimensions.
\end{abstract}

At some point in the mid- to late twelfth century, the monastery of Grafschaft in Westfalia produced a nondescript manuscript containing a unique collection of theological, hagiographical, and literary works. Housed today in the Darmstadt Universitäts- und Landesbibliothek, this miscellany brought together a number of texts that constitute a complex reflection on the politics and theology of holy war in the wake of the Second Crusade, and in particular the so-called Wendish Crusade of 1147-49. The contents include works such as Hrabanus Maurus's commentaries on Esther and Judith, the vita of emperor Henry II, the Passion of Archbishop Thiemo (a Bavarian prelate killed on the Crusade of 1101), and the so-called Magdeburg Crusade Letter. ${ }^{1}$ The contents of Darmstadt,

The research for this article was supported by the Hamilton College Dean of Faculty and the Institute for Medieval Research of the Austrian Academy of Sciences in cooperation with the ERC AdG Project SCIRE (No. 269591). I thank in particular Walter Pohl, Max Diesenberger, Christina Glassner, and Franz Lackner at the Institute for their assistance and support. I also thank participants in the October 2013 California Medieval History Seminar and Prof. Suzanne Yeager for their insightful comments and critiques on an earlier version of this paper.

${ }^{1}$ Die Handschriften der Hessischen Landes- und Hochschulbibliothek Darmstadt, ed. Kurt Hans Staub and Hermann Knaus, vol. 4 (Wiesbaden, 1979), no. 110, pp. 176-79. The 
Cod. 749 - and in particular the copy of the Passion of Archbishop Thiemo (BHL 8232) it contains - reveal how one local monastic institution in northern Germany might have sifted its inheritance of theological, historical, and hagiographical writings in an attempt to explore and understand sanctified violence in both the Slavic East and in the Crusades to the Holy Land. ${ }^{2}$ Indeed, the interplay of these texts suggests that its compiler(s) were looking at ways of understanding these conflicts in dynamic relationship with one another.

The postcolonial turn in cultural and historical studies over the past generation, along with the growing field of Crusade studies, has produced a rich body of scholarship on medieval "orientalism" and the construction of the cultural Other in the literary and historiographical traditions of the Latin West. ${ }^{3}$ While much of this scholarship has been focused on the Mediterranean, the frontiers of Northern Europe and Scandinavia have also received due attention in recent years as environments that produced important textual reflections on religious and ethnic identity during successive waves of Latin European expansion. ${ }^{4}$ Together, however, all these studies have tended to rely principally on close, richly contextualized readings of individual authors or texts - such as the Chanson de Roland or Helmold of Bosau's Chronica Sclavorum - that elucidate processes of Christian identity formation and the transmission of certain images of Islam, pagans, or other non-European peoples and places. At the same time, the turn towards "manuscript philology" over the past twenty years has opened up a number of new interpretive vistas, both in history and literary

contents are also discussed in detail by Wilhelm Wattenbach, "Handschriftliches II. Codex bibl. Darmstadt 749," Neues Archiv 7 (1882): 621-29.

${ }^{2}$ For an older assessment, see the collection of essays in Heidenmission und Kreuzzugsgedanke in der deutschen Ostpolitik des Mittelalters, ed. Helmut Beumann (Darmstadt, 1963; repr. 1973).

${ }^{3}$ Several essential works now include: John V. Tolan, Saracens: Islam in the Medieval European Imagination (New York, 2002); Geraldine Heng, Empire of Magic: Medieval Romance and the Politics of Cultural Fantasy (New York, 2003); Sharon Kinoshita, Medieval Boundaries: Rethinking Difference in Old French Literature (Philadelphia, 2006); Suzanne Conklin Akbari, Idols in the East: European Representations of Islam and the East, 11001450 (Ithaca, 2009); and most recently Jerald C. Frakes, Vernacular and Latin Literary Discourses of the Muslim Other in Medieval Germany (New York, 2011). For a theoretical orientation, see the important collection of essays in The Postcolonial Middle Ages, ed. Jeffrey Jerome Cohen (New York, 2000).

4 Latin European expansion into Eastern Europe and the Baltic is given equal treatment with the Mediterranean expansion in Robert Bartlett, The Making of Europe: Conquest, Colonization, and Cultural Change, 950-1350 (Princeton, 1993). See more recently, David Fraesdorff, Der barbarische Norden: Vorstellungen und Fremdheitskategorien bei Rimbert, Thietmar von Merseburg, Adam von Bremen und Helmold von Bosau, Orbis mediaevalis 5 (Berlin, 2005); and Lisa Wolverton, Cosmas of Prague: Narrative, Classicism, Politics (Washington, DC, 2014). 
studies. ${ }^{5}$ Manuscript, or material, philology, is a way of thickly describing medieval texts as constituted within a manuscript "matrix" that, as Stephen Nichols put it, speaks to the "social, commercial, and intellectual organization at the moment of its inscription." 6 This methodology has been current in vernacular literary studies, as well as early medieval history (especially Carolingian studies), for some time now, and has more recently begun to emerge among scholars working on discourses of alterity and images of the East. ${ }^{7}$ Andrew Taylor's study of the Oxford Roland manuscript (Bodleian Library, Digby 23) and the implications of the famous epic's inclusion alongside Calcidius's translation of Plato's Timaeus, as well as Iain Macleod Higgins's analysis of the manuscript tradition of Mandeville's Travels, are examples of the way attention to content and materiality have led to provocative new insights about some of the key works in the canon of medieval writing on the cultural and religious Other, particularly how the reception and interpretation of a work can change as it is recopied into new manuscript contexts over time. ${ }^{8}$

5 An essential introduction is the article by Stephen G. Nichols, "Philology in a Manuscript Culture," Speculum 65 (1990): 1-10.

6 Stephen G. Nichols and Siegfried Wenzel, eds., The Whole Book: Cultural Perspectives on the Medieval Miscellany (Ann Arbor, 1996), 1.

7 The work of Rosamond McKitterick and Walter Pohl, as well as that of their students, has been fundamental in reorienting the study of early medieval historiography around original manuscripts. See, e.g., Rosamond McKitterick, History and Memory in the Carolingian World (Cambridge, 2004); Walter Pohl, Werkstätte der Erinnerung: Montecassino und die Gestaltung der langobardischen Vergangenheit, Mitteilungen des Instituts für österreichische Geschichtsforschung, Ergänzungs-Band 39 (Vienna and Munich, 2001); Helmut Reimitz, "Ein karolingisches Geschichtsbuch aus St. Amand: Der Cvp 473," in Text, Schrift und Codex: Quellenkundliche Arbeiten aus dem Institut für Österreichische Geschichtsforschung, ed. Christoph Egger and Herwig Weigl, Mitteilungen des Instituts für österreichische Geschichtsforschung, Ergänzungs-Band 25 (Vienna, 2000), 34-90; Marek Thue Kretschmer, Rewriting Roman History in the Middle Ages: The Historia Romana and the Manuscript Bamberg, Hist. 3, Mittellateinische Studien und Texte 36 (Leiden, 2007). Julia Crick's pathbreaking study of the manuscripts of Geoffrey of Monmouth and in particular her analysis of the texts associated with it - among which were a number of texts relating to the East - is another key work in the field. See The Historia Regum Britanniae of Geoffrey of Monmouth, vol. 4, Dissemination and Reception in the Later Middle Ages (Woodbridge, 1991).

8 Iain Macleod Higgins, Writing East: The Travels of Sir John Mandeville (Philadelphia, 1997); Andrew Taylor, Textual Situations: Three Medieval Manuscripts and Their Readers (Philadelphia, 2002), chap. 2. See too Suzanne Yeager, "World Translated: Marco Polo's Le Devisement dou monde, The Book of Sir John Mandeville, and Their Medieval Audiences," in Marco Polo and the Encounter of East and West, ed. Suzanne Conklin Akbari, Amilcare A. Iannucci, and John Tulk (Toronto, 2008), 156-81. On the history and transmission of Marco Polo's Devisement du monde, see now Christine Gadrat-Ouerfelli, Lire Marco Polo au Moyen Age: Traduction, diffusion et réception du Devisement du monde, Terrarum Orbis 12 (Turnhout, 2015); and Consuelo Dutschke, "Francesco Pippino and the Manuscripts of Marco Polo's Travels" (PhD diss., University of California, Los Angeles, 1993). 
The formation and reproduction of discourses of cultural alterity, religious identity, and historical change did not take place in response to an individual text or author so much as to clusters or convoys of texts, assembled in collections like Darmstadt, Cod. 749, which were intended to be read and interpreted alongside one another. Like early medieval chronicles, individual works on crusades, Saracens, pilgrimage, apocalyptic, and Orientalia more generally rarely traveled alone in medieval libraries; they were almost always assembled in dossiers of geography, historiography, or theology whose thematic coherence should be taken into account if we are to appreciate how the individual works were actually read and interpreted by medieval audiences. ${ }^{9}$ Albert Derolez has referred to the "associative organization" of encyclopedic compilations, like the Liber Floridus of Lambert of St.-Omer, where "mental associations evoked by one chapter become the subject of the next." 10 As with Lambert's great codex, the contents of a manuscript like Darmstadt 749 do not necessarily follow a strict thematic or chronological order, but each individual work or text resonates with an image or idea suggested in one of the other texts around it in a way that permits a reader to discern some of the larger issues with which the copyist or compiler was concerned. Further accretions and additions over time attest to the fact that the codex was known and remembered as a repository of material relevant to certain questions and discussions about pagans, Crusading, and Christianity in the East.

Many of these so-called Sammelhandschriften or receuils, particularly from the twelfth and thirteenth centuries, would thus repay closer examination as whole objects used by scribes and their communities to negotiate the meanings and boundaries of cultural and religious difference in particular. Paolo Chiesa, for example, has shown how material on fantastical voyages, the wonders of the East, and saints associated with India, such as St. Thomas or Barlaam and Josephat, are often transmitted together in manuscript dossiers that he describes as "basi di conoscenza del mondo del tardo medioevo." 11 It is precisely in the context of these "knowledge bases," combining often heterogeneous genres and

9 In addition to the introduction to Nichols and Wenzel, eds., The Whole Book, see too the brief but theoretically rich "Epilogue" by Ardis Butterfield in Le receuil au Moyen Age: Le Moyen Âge central, ed. Yasmina Foehr-Janssens and Olivier Collet (Turnhout, 2010), 269-77.

10 The Autograph Manuscript of the Liber Floridus: A Key to the Encyclopedia of Lampert of St.-Omer, Corpus christianorum autographa medii aevi 4 (Turnhout, 1998), 182. I thank an anonymous reader for Traditio for suggesting Derolez's formulation here.

11 "Il contributo dei testi agiografici alla conoscenza dell'oriente nel medioevo latino," in Tra edificazione e piacere della lettura: le vite dei santi in età medievale, ed. Antonelle Degl'Innocenti and Fulvio Ferrari (Trent, 1998), 9-29, quotation on 27. See too Anežka Vidamanová, “Die mittellateinische 'Belletristik' als Mittel zum Kennenlernen von fremden Ländern im Königreich Böhmen zur Zeit der Luxemburger," in King John of Luxembourg (1296-1346) and the Art of His Era, Proceedings of the International Congress, Prague, September 1620, 1996 (Prague, 1998), 46-52; Walter Pohl, “History in Fragments: Monte Cassino's Politics of Memory," Early Medieval Europe 10 (2001): 343-374, at 350-51. 
texts, that we have to interpret medieval descriptions of Islam and the East, or of the exotic, non-Christian Other. Different communities of readers assembled texts in order to explore different associations and meanings within them. For the Crusades more specifically, we know from the research of Jay Rubenstein that medieval copyists carefully curated compilations of Crusader histories in an attempt to preserve the memory of heroic deeds as well as inspire new Crusaders to emulate past greatness. ${ }^{12}$ Yet these same texts, like the chronicle of Robert the Monk, were not only translated into vernacular languages and even versified, but could migrate from historical collections to theological/geographical miscellany, to end up as a basic travel guide to the Holy Land. ${ }^{13}$ What questions were the readers of these books asking, and what answers did they hope to find in the various groupings of Crusade literature, epic romance, geography, and theology that we encounter? Aside from studies like Rubenstein's, which was able to situate its manuscript in a remarkably specific historical moment, we do not yet have a clear answer to such questions. In the following, however, I hope to demonstrate an approach to such works in the context of their "associative organization" that might be extended to a variety of places and periods.

\section{The Manuscript}

Darmstadt, Universitäts- und Landesbibliothek, Cod. 749 originally belonged to the Benedictine abbey of Grafschaft, a reformed community situated roughly midway between Cologne and Kassel in Westfalia. Grafschaft was founded by Anno II of Cologne in 1072 and settled with monks from Siegburg, his showcase reform monastery. ${ }^{14}$ The book is a modest octavo volume in a modern (nineteenth-century) binding, measuring roughly $20 \times 13 \mathrm{~cm}$, whose leaves have been pricked and ruled consistently throughout. ${ }^{15}$ Although the manuscript was rebound in the nineteenth century, it still preserves on its first page (fol. 1v) an ex libris and table of contents in a bold gothic hand of the fifteenth century a strong indication that the modern rebinding did not fundamentally alter the content or order of the original material (see Fig. 1). ${ }^{16}$ The texts themselves are contained in two major groups of gatherings (quaternions) that appear to have

12 Jay Rubenstein, "Putting History to Use: Three Crusades Chronicles in Context," Viator 35 (2004): 131-68.

13 Cf. Thomas Martin Buck, "Von der Kreuzzugsgeschichte zum Reisebuch: Zur Historia Hierosolymitana des Robertus Monachus," Deutsche Vierteljahresschrift für Literaturwissenschaft und Geistesgeschichte 76 (2002): 321-55.

14 "Grafschaft," Germania Benedictina (St. Ottilien, 1980), 8:351-76, s.v.

15 Die Handschriften der hessischen Landes- und Hochschulbibliothek Darmstadt (n. 1 above), no. 110, pp. 176-79.

16 Fol. 1v: "Liber S. Alexandri in Grascaph ... Expositio Rabani in libros Judith et Hester; Vita Sci Heinrici imperatoris et miraculi; Passio S. Ignatii epi; Passio sci Thiemonis 


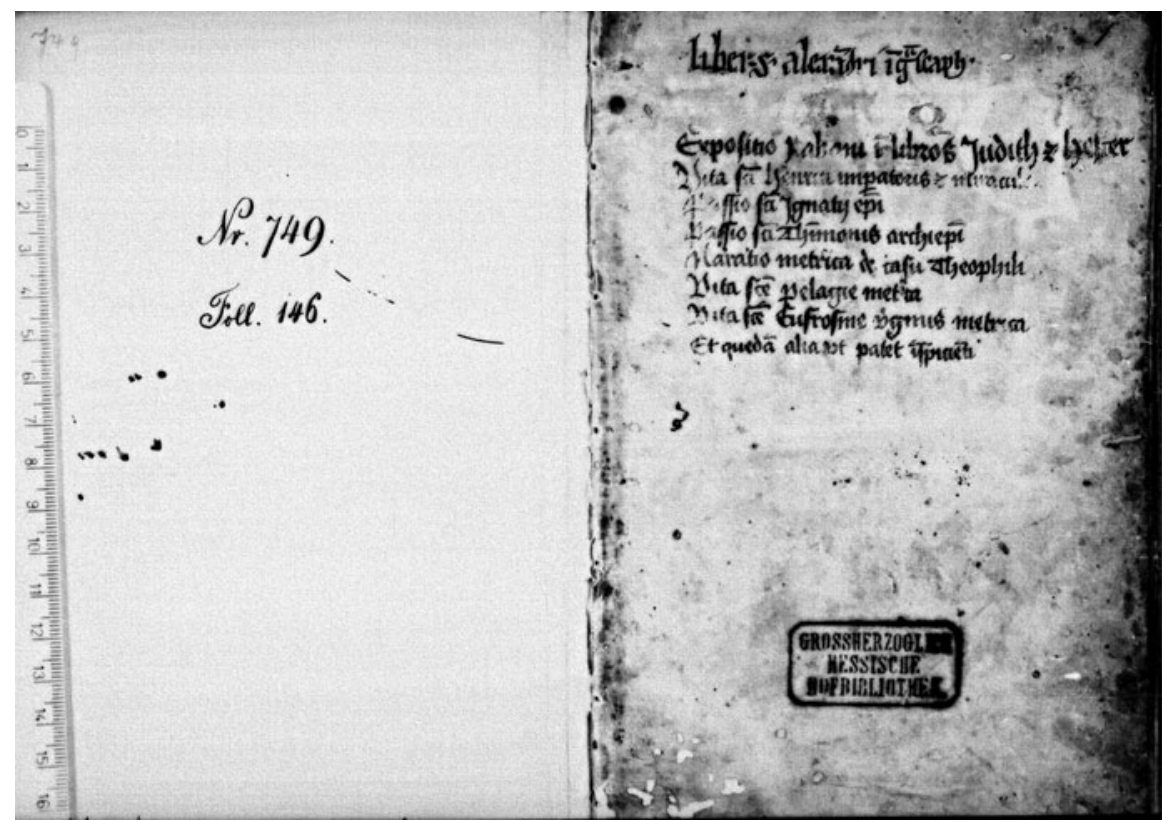

Figure 1: Darmstadt, Cod. 749, fol. 1r. Late-medieval ex libris and table of contents. Reproduced with the permission of the Universitäts- und Landesbibliothek Darmstadt.

been bound together in the mid- to late twelfth century. We may take some material relating to the Cologne archbishop Rainald of Dassel (d. 1167) in the last gathering (fols. 137-45) as a rough terminus post quem, but we cannot know for certain how long after the composition or binding of the original contents it may have been added or if indeed it may have been part of the original conception of the codex. About a dozen of the gatherings are palimpsests (with new ruling perpendicular to the old) of some otherwise unidentifiable theological and liturgical works from the ninth and tenth centuries. ${ }^{17}$ Never a wealthy monastery, Grafschaft had several other early manuscripts that show evidence of this common salvage technique. ${ }^{18}$ With the exception of a few minor additions at the end of the last gathering, all the works in the main sections of the codex were copied in one or two very similar, consistent twelfth-century book hands. The book's construction and coherence of material, along with the late-medieval table of contents, should leave us with a high degree of confidence that it was

archiepi.; Narratio metrica de casu Theophili; Vita sce Pelagie metrica; Vita sce Euphrosine v [ir]ginis metrica; Et quedam alia ut patet i[n]spicie[n]ti."

17 Wattenbach, "Handschriftliches" (n. 1 above), 622. See too Staub and Knaus, Handschriften (n. 1 above), 179 for further details.

18 Cf. Darmstadt, Codd. 752; 754. 
conceived and executed as a single project. ${ }^{19}$ One later addition, namely, an account of the miracles of St. Thomas of India copied onto extra space left on fols. 88v-89r, appears to date from late twelfth or early thirteenth century, suggesting that even after the main sections were complete, the book continued to serve as a place for copyists to insert material related to its broader themes.

The first eighty-eight folios consist of ten numbered gatherings copied in a single hand and contain the commentaries on Esther and Judith by Hrabanus Maurus (fols. 1-85r), some brief excerpts from Isidore's Etymologiae (85v-86v) on rhetoric and oratory (mostly Book 2, chaps. 3-5), and, notably, the so-called "Crusade Letter" of archbishop Adelgoz of Magdeburg (86v-88v). Two later hands (late twelfth/early thirteenth c.?) with more pronounced proto-gothic features recorded a text labeled Narratio de Miraculis S. Thomae (abridged version of BHL 8146) on the remaining page and a half following the letter (88v-89r). A second section of the codex, consisting of eight (unnumbered) quaternions (fols. 89-145), and copied in the same hand as the first section, contains a group of narrative saints' lives: the Vita sancti Heinrici imperatoris (BHL 3182), Passio S. Ignatii (BHL 4256), and the Passio Thiemonis by Heinrich of Breitenau (BHL 8132).

The sections of exegesis and prose hagiography also feature consistent styles of rubrication and, notably, characteristically large initial letters (six-line) at the beginning of each text. Following these - again, in the same hand - there is a hagiographical corpus in verse ascribed to the monk Gevehard of Grafschaft. ${ }^{20}$ These include: metric reécritures of the De casu Theophili vicedomini, the Vita S. Pelagiae, and the Vita S. Eufrosiniae (fols. 117r-136v). On the last half-folio of $137 \mathrm{v}$, and continuing on a new gathering (fols. 138r-139v), follow a brief metric panegyric for the late Cologne archbishop Rainald of Dassel (136v-137r) by Gevehard, a laudatory poem addressed to abbot Nicholas of Siegburg (d. 1172) (134v-135r), and another letter-poem addressed to a monk of Soest abbey named Wernherus $(135 \mathrm{r}-\mathrm{v}) .{ }^{21}$ These verses are copied in a similar hand as the rest of the preceding material. The last several folios, beginning on 140r, contain some letters from the congregation and an abbot of Grafschaft to archbishop Rainald (140r-143v), some verses on the legendary founding of Trier $(143 v-145 r)$, and a story about an apparition that had appeared to the monks

19 Cf. too the observations of Wattenbach, "Handschriftliches," 623: "Aber Material und Schrift sind ganz gleichartig, und sie müssen gleichzeitig entstanden und sehr früh verbunden sein."

20 Wattenbach first suggested that the metric saints' lives were probably also by the same author as the Epitaphium Rainaldi, that is, Gevehard. See "Handschriftliches," 623. For further discussion, see below, n. 123.

21 The Epitaphium Reinaldi is printed in Regesten der Erzbischöfe von Köln, ed. Richard Knipping (Bonn, 1901), 2:161. 
of Affligem in Brabant (145v). These last three items are all in distinctly different hands from the rest of the last gathering and appear somewhat younger. The story about Affligem is no longer legible but was published by Wattenbach in an appendix to his description of the codex. ${ }^{22}$

Table 1. Contents of Darmstadt, Cod. 749

\begin{tabular}{|c|c|c|}
\hline Fol. & Work & Hand \\
\hline $1 \mathrm{v}-50 \mathrm{v}$ & Hrabanus Maurus, Expositio in Librum Judith & 1 \\
\hline $50 v-85 r$ & $\begin{array}{l}\text { Hrabanus Maurus, Expositio in librum Hester (incl. } \\
\text { dedication to Queen Judith) }\end{array}$ & 1 \\
\hline $85 v-86 v$ & $\begin{array}{l}\text { Isidore of Seville, excerpts from Book } 2 \text { of the Ety- } \\
\text { mologiae on rhetoric and the arts }\end{array}$ & 1 \\
\hline $86 v-88 v$ & $\begin{array}{l}\text { Adelgoz of Magdeburg, Epistola ad Episcopos Saxo- } \\
\text { niae et al. }\end{array}$ & 1 \\
\hline $88 v-89 r$ & De miraculis S. Thomae apostoli (BHL 8146) & 4,5 \\
\hline $89 v-104 v$ & Vita S. Heinrici (BHL 3812) & 1 \\
\hline $105 v-113 v$ & Passio S. Ignatii (BHL 4256) & 1 \\
\hline $114 \mathrm{r}-116 \mathrm{v}$ & $\begin{array}{l}\text { Heinrich of Breitenau, Passio S. Thiemonis (BHL } \\
\text { 8132) }\end{array}$ & 1 \\
\hline $116 v-124 \mathbf{r}^{23}$ & De casu Theophilii ... metrica & 1 \\
\hline $124 \mathrm{r}-129 \mathrm{r}$ & Vita metrica S. Pelagiae & 1 \\
\hline $129 \mathrm{r}-136 \mathrm{v}$ & Vita metrica S. Euphrosinae & 1 \\
\hline $136 \mathrm{v}-137 \mathrm{r}$ & Epitaphium Reinaldi & 1 \\
\hline $137 \mathrm{v}-138 \mathrm{r}$ & Gevehard, Littera metrica ad Nicholam abbatum & 1 \\
\hline $138 \mathrm{r}-139 \mathrm{v}$ & Gevehard, Littera metrica ad Wernherem monachum & 1 \\
\hline $140 \mathrm{r}-143 \mathrm{v}$ & $\begin{array}{l}\text { Letters from the community of Grafschaft to } \\
\text { Rainald of Dassel }\end{array}$ & $1 \& 2$ \\
\hline $143 \mathrm{v}-145 \mathrm{r}$ & Verses on the foundation of Trier & 3 \\
\hline $145 \mathrm{v}-146 \mathrm{r}$ & Vision from the monastery Afflighem & ? (illegible) \\
\hline
\end{tabular}

Stories about confrontations between Christians and pagans and/or Saracens seem to be a thread running through the selection of texts, particularly in two main sections of the manuscript. The saints and other historical and biblical figures assembled here form a bulwark of heroic resistance against the violence and madness of pagans. The manuscript's compiler or compilers set out to create a compendium of hagiographically inflected salvation history from biblical

22 Wattenbach, "Handschriftliches," 628-29.

23 Staub and Knaus, Handschriften, 177 (n. 1 above) erroneously gives the folio range as 116v-117r. 
antiquity to the recent past that could help contemporary readers place current (or recent) events, such as the Second Crusade and the call to forcibly convert the West Slavs, in a broader context. These contents illuminate what must have been a broader problematic for monastic readers in Saxony or Westfalia in the mid- to late twelfth century, namely, how to understand ongoing efforts to rescue the Holy Land in relationship to traditional understandings of paganism and earlier Christian conflicts with idolatry and unbelief. While the writings of individual promoters and participants like Bernard of Clairvaux or Otto of Freising have traditionally provided historians with insights about how contemporaries understood the various dimensions of the Second Crusade (and its failures), a manuscript like this one offers a heretofore unavailable opportunity to explore the scribal and textual practices that shaped monastic (and perhaps clerical) perceptions about Christian and pagan identity.

\section{The Historical Context}

It makes sense to understand the codex's compilation as an attempt to place the Wendish Crusade of 1147-48 — and perhaps the Second Crusade as a whole - into a larger historical and theological context. Scholars have increasingly come to recognize that, for contemporaries, the Second Crusade was more than a targeted expedition to retake Edessa or defend the Latin Kingdom in the East. Rather, it was conceived as a campaign of total war against unbelief and threats to Christendom on at least three fronts. ${ }^{24}$ While the main armies of Louis VII and Conrad III sought (unsuccessfully) to roll back Muslim advances in the East, Eugenius simultaneously sanctioned crusades against Muslims in Iberia, as well as against pagans beyond the Elbe River in Saxony. While the purpose of this last campaign, launched in the summer of 1147, was to advance the Christianization of the so-called "Wends" — a catchall term for the diverse constellation of West Slavic peoples between the Elbe and Oder rivers - the politics of this Transalbian frontier situated between the German, Danish, and Polish kingdoms had for several centuries been defined by a complex admixture of religious violence, missionary zeal, and pragmatic accommodation. ${ }^{25}$

24 Giles Constable, "The Second Crusade as Seen by Contemporaries," Traditio 9 (1953): 213-79, repr. in Crusaders and Crusading in the Twelfth Century (Surrey and Burlington, VT, 2008), 229-300 first made the case that twelfth-century writers had a much more expansive view of the Crusade project than modern scholars tended to acknowledge. Constable's view has since become a well-established framework for studying the Crusade, e.g., in Jonathan Phillips, The Second Crusade: Extending the Frontiers of Christendom (New Haven, 2007).

25 On the Wendish Crusade, and the history of the German-Slavic frontier generally, the best English-language treatment, in addition to Phillips, Second Crusade, 228-43, is Friedrich Lotter, "The Crusading Idea and the Conquest of the Region East of the Elbe," in Medieval Frontier Societies, ed. Robert Bartlett and Angus McKay (Oxford, 1989), 267-306. 
The region between the Elbe and the Oder in northern Germany had been organized as a series of marcher counties since the mid-tenth century when the Ottonians reduced the Slavic tribes there to tributary status and erected a series of fortifications and churches to promote Christianization. ${ }^{26}$ On the lower Elbe, bishoprics were established at Mecklenburg, Ratzeburg, and Oldenburg for the Abrodites and placed under the archbishop of Hamburg-Bremen, while, further south, new dioceses were created for the Liutizians at Havelberg and Brandenburg and subordinated to the new archiepiscopal see created at Magdeburg in 968. Like the pagan Saxons before them, however, the Slavic tribes engaged their stronger neighbors in a lengthy cycle of submission and resistance designed to optimize their autonomy. ${ }^{27}$ Some Slavic groups and their rulers embraced Christianity and cultivated close political relationships with their German counterparts and their churches, but others remained staunchly resistant to Christianization and submission to either Polish or German (and later Danish) influence. Major rebellions in 983, and again in 1066, led by pagan factions among the Slavic tribes left the northern marches and their churches in disarray for decades. ${ }^{28}$ While memories of pagan atrocities against the Christians endured, only sporadic attempts were made at retribution or reestablishing full control over the region. ${ }^{29}$ Bishop Burchard II of Halberstadt led a reprisal raid deep into Liutizian territory in 1068, returning with plunder that included a sacred white horse from the pagan shrine at Rethra. ${ }^{30}$ In 1108, archbishop Adelgoz of Magdeburg (or his amanuensis) published a letter - preserved uniquely in Darmstadt, Cod. 749 and discussed in further detail below - reminding readers of the outrages committed by the infidels and calling for all Germans to unite in a crusade to extirpate the pagan Slavs in imitation of the heroic knights who had recently liberated the Holy Land. ${ }^{31}$ This appeal failed to generate a coherent response, however. The local nobles seemed mostly content to establish rural settlements using peasant farmers

26 Timothy Reuter, Germany in the Early Middle Ages, 800-1056 (Harlow, UK, 1991), 160-66; Gerd Althoff, "Saxony and the Elbe Slavs in the Tenth Century," in The New Cambridge Medieval History (Cambridge, 2015), 3:267-92.

27 Althoff, "Saxony and the Elbe Slavs," 280.

28 Lotter, "Conquest," 271-72.

29 The chronicler Adam of Bremen provided a particularly vivid description of the violence that accompanied the 1066 uprising. See History of the Archbishops of HamburgBremen, 3.50 (49)-51 (50), trans. Francis J. Tschan (New York, 1959; repr. 2002), 157-58.

30 Gerold Meyer von Knonau, Jahrbücher des deutschen Reiches unter Heinrich des IV. und Heinrich des V., 7 vols. (Leipzig, 1890-1909), 1:585-86. Cf. Annales Augustana, MGH SS 3, 128 , s. a. 1068 .

31 Giles Constable, "Early Crusading in Eastern Germany: The Magdeburg Charter of 1107/8," in Crusaders and Crusading, 197-214. 
recruited from other areas of northern Germany and to collect taxes and tribute from the Slavic tribes under their jurisdiction. ${ }^{32}$

In 1144, the Turkish emir Zengi captured the strategically (and historically) crucial city of Edessa in northern Syria, prompting Pope Eugenius III to summon a new crusade to help defend the Holy Land. ${ }^{33}$ Inspired by the preaching of Bernard of Clairvaux, Louis VII of France took the cross in March 1146, and Conrad III, along with a large number of the German nobility, followed later in December of the same year. ${ }^{34}$ The dramatic setback of Christian fortunes in the Levant threw other forms of religious conflict into sharper relief, particularly in Germany. In the Rhineland, a Cistercian monk named Radulf, or Ralph, urged his listeners to take up the cross, but also encouraged attacks on Jews that revived memories of the devastating pogroms of the First Crusade. ${ }^{35}$ Arnold, the archbishop of Cologne, opened the great fortress of Wolkenburg to the Jews of the city as mobs of Crusaders sought to destroy them. ${ }^{36}$ Bernard traveled to Germany in the fall of 1146 to silence Ralph, as well as to encourage Conrad III and other German nobles to join Louis VII on the expedition to the East. ${ }^{37}$ Conrad did eventually take the cross at Speyer in December 1146, but, at an imperial diet at Frankfurt the following spring (March 1147), Bernard met with a number of Saxon nobles and afterward published a letter announcing a crusade to conquer and convert the rebellious pagan Slavs east of the Elbe River. ${ }^{38}$ Bernard directed that "those nations should either be fully converted to the Christian faith, or utterly exterminated," and - apparently assuming in advance that he spoke for the pope — that anyone who took up the cross against the pagan Slavs

32 Lotter, "Conquest," 273-74, referring to the observation of Helmold of Bosau, Chronicle of the Slavs, 1.56, ed. B. Schmeidler, MGH SS rer Germ. 23 (Hanover, 1937), trans. Francis J. Tschan (New York, 1935), 167, that they were mostly "accustomed to watch over the Slavs for the purpose of increasing their incomes."

33 Phillips, Second Crusade, 37-60.

34 Regesta Imperii, vol. 4, 1.2, no. 421, accessed 24 March 2015, http://www.regestaimperii.de/id/1146-12-24_1_0_4_1_2_423_421.

35 Phillips, Second Crusade, 84-88. Otto of Freising provides an extensive account of Ralph's preaching and Bernard's efforts to combat it. See Deeds of Frederick Barbarossa, 1.38(37)-39(38), trans. Christopher J. Mierow (New York, 1953; repr. 2004), 74-75. While the forcible conversion of Jews was technically not permitted in Christian law, Jews were increasingly viewed in the twelfth century as a pernicious and destabilizing presence in Christian society. On the place of Jews in the medieval Christian imagination, see Jeremy Cohen, Living Letters of the Law: Ideas of the Jew in Medieval Christianity (Los Angeles and Berkeley, 1999), and 147-66 in particular on the growth of anti-Judaism in the twelfth century.

36 Wilhelm Bernardi, Jahrbücher des deutschen Reiches unter Konrad III, 2 vols. (Leipzig, 1883), 2:523.

37 Otto of Freising, Deeds of Frederick Barbarossa, 1.39(38)-40 (39), trans. Mierow, 74-76.

38 Jean Le Clercq et al., eds., Sancti Bernardi Opera, 8 vols. in 9 (Rome, 1957-98), 8:pt. 2 (hereafter Epistolae), no. 457, pp. 432-33. See too idem, "L'Encyclique de saint Bernard en faveur de la Croisade," Revue bénédictine 81 (1971): 282-308. 
would receive the same plenary indulgence as those going to Jerusalem. ${ }^{39}$ Furthermore, he forbade ("interdicimus") the participants to enter into any pact with, or to accept payment or tribute from, the enemy until "with God's help, either their rite [viz. paganism], or their nation, is destroyed."40

One month later in Dijon, Pope Eugenius received a delegation from the German kingdom that informed him about what had transpired at Frankfurt, and he issued another encyclical that acknowledged the broadened scope of the Crusade, which now aimed to combat the infidels not only in the Holy Land but also in Spain and in the northern lands. ${ }^{41}$ The letter does not adopt Bernard's rhetoric about compelling conversion but does state that the aim of the northern Crusade would be to subjugate "Slavs and other pagans" to Christianity. Perhaps uneasy about having to endorse a project he had not been fully informed about from the start, and wary of the Saxons' motives, he appointed one of the German envoys, bishop Anselm of Havelberg, as the official papal legate for the expedition, encouraging him to maintain unity among the participants and see that the Crusade advanced the conversion of the pagans. ${ }^{42}$

The historical motivations and theological justifications for launching a formal crusade against the Wends - whether to destroy or convert them — are difficult to discern clearly, both in terms of the immediate situation on the Transalbian frontier as well as in the context of the broader goals of the Second Crusade to the east. Bernard of Clairvaux's direct involvement in conceiving and setting in motion the organization of a crusade against the Slavs has been the subject of a great deal of study and debate. Friedrich Lotter, most notably, has suggested that Bernard did not envision the literal extermination of Slavs who did not embrace Christianity — which would have run contrary to longstanding Christian teachings against conversion under compulsion - but rather that he understood

39 "Et ad delendas penitus, aut certe covertendas nationes illas." Bernard, Epistolae, no. 432. On the Frankfurt diet and Bernard's meeting with the Saxons, see Regesta Imperii, vol. 4, 1.2 no. 446, accessed 24 March 2015, http://www.regesta-imperii.de/id/1147-0313_1_0_4_1_2_448_446; and further, Hans-Dietrich Kahl, "Wie kam es 1147 zu einem Wendenkreuzzug?" in idem, Heidenfrage und Slawenfrage im deutschen Mittelalter: Ausgewählte Studien, 1953-2008 (Leiden, 2008), 623-32.

40 "Illud enim omnimodis interdicimus, ne qua ratione ineant foedus cum eis, neque pro pecunia, neque pro tributo, donec, auxiliante Deo, aut ritus ipse, aut natio deleatur." Bernard, Epistolae, no. 433.

41 "Rex quoque Hispaniarum contra Saracenos de partibus illis potenter armatur, de quibus iam per Dei gratiam saepius triumphavit. Quidam etiam ex vobis tam sancti laboris et praemii participes fieri cupientes, contra Sclavos caeterosque paganos habitantes versus Aquilonem ire, et eos Christianae religioni subiugare, Domino auxiliante, intendunt." Divini dispensatione (JL 9017), PL 180:1203A. On this bull, see now Iben Fonnesberg-Schmidt, The Popes and the Baltic Crusades, 1147-1254, The Northern World 26 (Leiden, 2007), 31-34.

42 See too Jay T. Lees, Anselm of Havelberg: Deeds into Words in the Twelfth Century (Leiden, 1998), 78. 
the Crusade as an effort to reimpose Christian order on a people who had once embraced it but then rebelled. ${ }^{43}$ Lotter's views have not gained universal assent. Hans-Dietrich Kahl, for example, has argued that Lotter overlooked the eschatological significance of Bernard's conceptual vocabulary in the Crusade letter and his other writings that drew upon the Sybilline prophecies and the legend of the Last Emperor. ${ }^{44}$ The so-called Tiburtine Sybil was a late Roman apocalyptic text that held that as the end times approached, a certain "C. rex Romanorum" would rise up to destroy the unbelievers and save Jerusalem. ${ }^{45}$ Kahl speculates that after Conrad agreed to participate in the expedition to Jerusalem in December 1146, Bernard's view of the Crusade took a dramatic new turn, and he began to see not just an opportunity to defend the Holy Land but to herald the end times themselves by advancing the conversion of the heathen. Thus when Bernard quoted Psalm 149:7 in his letter about God "taking vengeance against the nations" and "extirpating [them] from the land of the Christian name" ("ad faciendam vindictam in nationibus et extirpandas de terra Christiani nominis"), he referred not literally to the "land" of the Saxons but to the whole (Christian) world, which would be purified of the pagan rite. ${ }^{46}$ Kahl's thesis is, to a large extent, based on inference - Bernard never explicitly cites or refers to the Sybilline texts - and other scholars, in particular Bernard McGinn, have taken a more circumspect view of Bernard's eschatological views. ${ }^{47}$ Cod. 749 does not contain any overtly apocalyptic texts, which suggests that, at least in Grafschaft, the eschatological angle was not preeminent in their thinking about the Crusade.

43 See Lotter, "Conquest" (n. 25 above), 290-92, and, more expansively, idem, Die Konzeption des Wendenkreuzzugs: Ideengeschichtliche, kirchenrechtliche und historisch-politische Voraussetzungen der Missionierung von Elb- und Ostseeslawen um die Mitte des 12. Jahrhunderts (Sigmaringen, 1977), 38, 69, and passim.

44 Hans-Dietrich Kahl, "Auszujäten von der Erde die Feinde des Christennamens": Der Plan zum 'Wendenkreuzzug' von 1147 als Umsetzung sibyllinischer Eschatologie," in Heidenfrage und Slawenfrage, 631-64; idem, "Die Ableitung des Missionskreuzzuges aus sibyllinischer Eschatologie: Zur Bedeutung Bernhards von Clairvaux für die Zwangschristianisierungsprogramme im Ostseeraum," in Die Rolle der Ritterorden in der Christianisierung und Kolonisierung des Ostseegebietes, ed. Zenon Hubert Nowak, Ordines Militares 1 (Torún, 1983), 129-39. A brief, English-language précis of Kahl's arguments in the above works is idem, "Crusade Eschatology as Seen by Bernard in the Years 1146-48," in The Second Crusade and the Cistercians, ed. Michael Gervers (New York, 1992), 35-41.

45 On the Sybilline tradition and the legend of the Last Emperor, see now Hannes Möhring, Weltkaiser und Endzeit: Enstehung, Wandel und Wirkung einer tausandjährigen Weissagung, Mittelalter-Forschung 3 (Stuttgart, 2000).

46 Kahl, "Plan zum Wendenkreuzzug," 148-49.

47 Bernard McGinn, "St. Bernard and Eschatology," in Bernard of Clairvaux: Studies Presented to Dom Jean Le Clercq, Cistercian Studies 23 (Washington, DC, 1973), 161-95. Cf. too Möhring, Weltkaiser, 169-70 for a discussion of Kahl's views, with which Möhring disagrees, as well as the remarks of Peter Dinzelbacher, Bernhard von Clairvaux: Leben und Werk des berühmtesten Zisterzieners (Darmstadt, 1998), 304. 
Pegatha Jean Taylor, however, has recently underscored a different source of militant evangelization and the ethos of martyrdom on the eastern frontier, namely, the writings of monastic and clerical figures like Bruno of Querfurt, Adalgoz of Magdeburg, and Adam of Bremen that grew out of the experience of repeated setbacks in the effort to establish permanent Christian institutions across Sclavinia. ${ }^{48}$ Monastic writers in twelfth-century Germany, along with Bernard of Clairvaux himself, had been keenly interested in the relationship between active evangelization and the monastic vocation. As Taylor elucidates, conversion, both the kind of internal, spiritual reform envisioned in the monastic life and the evangelization of non-Christian people, came to have a special resonance for monastic writers in the Slavic bishoprics who saw the potential for personal and religious renewal in preaching to the heathen (and sometimes dying for this preaching). ${ }^{49}$ Just as Bernard had advocated the synthesis of monastic and knightly vocations in the creation of the Knights Templar in the 1120s, so also did he come to see the possibilities for religious renewal and reform - possibly also in an apocalyptic key — in the project of converting the Slavs and securely bringing the lands of the north into Christendom. These sentiments seem also to be those reflected in the composition of Cod. 749 .

Whatever Bernard's intentions may have been, the motives of the Saxon princes and prelates themselves in the Crusade were even less clear. By the mid1140 s, there had not been serious conflict between Slavs and Germans along the Elbe for nearly a decade, though Helmold of Bosau hints at ongoing pirate raids by the Slavs in Denmark that contributed to instability in the region. ${ }^{50}$ Albert the Bear of the Northmark enjoyed a close relationship with the Christian Slavic prince of Brandenburg, Heinrich-Pribislaw, and Count Adolf of Holstein even had a formal agreement at the time with Niclot, the pagan Slavic prince of Mecklenburg, to protect his interests in the region of Wagria, around Lübeck, where a nascent Christian community had begun to flourish. ${ }^{51}$ Anselm of Havelberg himself, though he desperately wished to see his titular see

48 Pegatha Jean Taylor, "Saint Bernard of Clairvaux and the West Slavic Crusade: The Formation of Missionary and Crusader Ideals on the German-Slavic Border" (PhD diss., University of California, Berkeley, 1999), chap. 2. See too Hans-Dietrich Kahl, "Compellere intrare: Die Wendenpolitik Brunos von Querfurt" in Staub and Knaus, Handschriften (n. 1 above), 183-210.

49 In addition to Taylor, "Bernard and the West Slavic Crusade," chap. 2, which explores these issues in depth, see eadem, "Moral Agency in Crusade and Colonization: Anselm of Havelberg and the Wendish Crusade of 1147," International History Review 22 (2000): 75784.

50 Chronicle of the Slavs (n. 32 above), 1.62, trans. Tschan, 175, also noted by Saxo Grammaticus, Gesta Danorum, 14.2.1, ed. J. Olrik and H. Raeder, 2 vols. (Copenhagen, 1931), 1:374. See Lotter, "Conquest," 290.

51 Hans-Dietrich Kahl, Slawen und Deutsche in der brandenburgischen Geschichte des 12. Jahrhunderts, 2 vols. (Cologne and Graz, 1964), 1:382-88. 
reestablished, may have harbored some reservations about the prospect of converting unbelievers by the sword, as opposed to preaching. ${ }^{52}$ Other contemporary sources that report on the Crusade cast a somewhat more jaundiced eye on the Crusaders' agenda. The Magdeburg Annals, composed at the monastery Berge in Magdeburg, contain a clear, if somewhat more sharply formulated, paraphrase of Bernard's directive, stating that the purpose of the expedition was "to subject them [viz. the Slavs] to Christianity, or, with God's help, utterly annihilate them." 53 The author describes the Crusade largely in terms of a plundering expedition that laid waste lands of the Slavs and burned their cities. Vincent of Prague's chronicle reported on the Crusader army that marched over the Lausitz into Pomerania, where it besieged the town of Stettin (Szczecin). Vincent wryly observed that the people of Stettin and their bishop had to inform the Crusaders that they had, in fact, already been converted by the preaching of Otto of Bamberg. ${ }^{54}$

The Crusade, such as it was, began in the summer of 1147 and concluded less than a year later with little accomplished. Niclot, furious that his erstwhile ally, Adolf of Holstein, had failed to stop the Crusaders harrying his lands, launched a devastating reprisal attack upon the settlements in Wagria. Helmold reports that at the siege of the Slavic fortress of Demmin, the vassals of duke Henry the Lion and margrave Albert even remarked upon the irony of attacking the very people who provided their lords" incomes. ${ }^{55}$ He later observed that, following the Crusade, "the Slavs still perform sacrifices to their demons and not to God, and they continue to make piratical incursions into the land of the Danes." 56 If the Saxon armies had been mobilized around Bernard's Crusade encyclical and its eschatological vision, they appear to have largely disregarded it or at least failed to let it inspire them to mount the grand imposition of Christian hegemony that it called for. ${ }^{57}$

We have no individual sources from Grafschaft that reflect on the outcome of the Crusade in the way Helmold and other annals and chronicles do, but Darmstadt Cod. 749 is itself a key piece of evidence for the fact that at least one community of Saxon-Westfalian monks attempted to organize a theological and historical response to the Crusade and the issues of conversion and martyrdom in particular. Though it did not lie directly on the frontier facing the threat from the pagans, Grafschaft would not have been isolated from discussions about the Crusade or its ramifications. Helmold of Bosau mentions that

\footnotetext{
52 Kahl, Slawen und Deutsche, 1:231. See too Lees, Anselm of Havelberg, 81.

53 "Eos aut christiane religione subderet, aut Deo auxiliante omnino deleret." MGH SS XVI, 188 .

54 MGH SS XVII, 663. On Otto's mission to the Pomeranians in the 1120 s, see A.P. Vlasto, The Entry of the Slavs into Christendom (Cambridge, 1970), 134-35. Stettin was the principal town and episcopal see of the Pomeranians.

55 Chronicle of the Slavs, 1.65, trans. Tschan, 180.

56 Ibid., 1.69, trans. Tschan, 188.

57 Kahl, Slawen und Deutsche, 1:225-35.
} 
Westfalians were among those who had settled in Count Adolf's lands. ${ }^{58}$ The monastery's direct superior at the time of the Crusade, archbishop Arnold I of Cologne (1138-51), had hosted Bernard during his preaching tour of the Rhineland, and, given the correspondence between the Grafschaft community and Rainald of Dassel that survives in the latter sections of Cod. 749 , it is certainly reasonable to assume that they maintained a similar level of contact with previous archbishops. Monks from Grafschaft may have even seen Bernard preach in or around Cologne and certainly may have known some of the knights and nobles who went to fight in 1147.

Arnold I's successor, the imperial chancellor Arnold of Wied (1151-56), had accompanied Conrad III to the east and was a close friend of both Anselm of Havelberg and the abbot Wibald of Corvey, another eminent promoter of the Wendish campaign. ${ }^{59}$ Arnold remained deeply committed to the ideology of crusading even after the dramatic failure of the Christian forces outside Damascus in July 1148. As archbishop-elect in 1151, Arnold dedicated a new church at Schwarzrheindorf, near Bonn, which contains a remarkable program of frescoes depicting Ezekiel's vision of the destruction of Jerusalem (Ezekiel 8) that Anne Derbes has shown to have strong connections to crusading ideology, particularly the desecration of holy places and the pollution of idolatry. ${ }^{60}$ Though we ultimately cannot trace the origins of Cod. 749 to a particular moment or individual, it clearly emerged from a theological-political milieu where questions of religious violence and conversion were being discussed and debated. The manuscript represents a similarly creative and ambitious attempt to connect fighting against the Slavs with the Crusade against the Saracens in a way that made explicit the longue durée of the struggle of God's people against their enemies, alongside miracles of conversion and penance. Like the frescoes at Schwarzrheindorf, it presents the conflict between heroic Christians and vicious pagans as being at the core of the crusading project but, as will become clearer in the subsequent analysis of the individual texts below, progresses towards a resolution in which the reader is also obliged to contemplate the stories of saintly conversion and penitential piety. These concerns do not map precisely onto either Bernard's or Eugenius's motivations, it appears, but, as Taylor's work has shown, they contributed to an ongoing discourse that attempted to reflect on Crusader militancy as a form of spiritual renewal. Moreover, it extends this thematic argument both

58 Chronicle of the Slavs, 1.57, 63, trans. Tschan, 168-69; 177-78.

59 Lees, Anselm of Havelberg, 19-21; Konrad Lübeck, "Abt Wibald von Stablo und Korvey und die Kölner Kirche," Annalen des historischen Vereins für den Niederrhein 140 (1942): 21-59. See too Heinz Wolter, Arnold von Wied: Kanzler Konrads III. und Erzbischof von Köln (Cologne, 1973).

60 "The Frescoes of Schwarzrheindorf, Arnold of Wied, and the Second Crusade," in The Second Crusade and the Cistercians (n. 44 above), 141-54; Wolter, Arnold von Wied, 51. Both Wibald of Corvey and Otto of Freising were present for the dedication as well. 
chronologically and geographically in a way that underscores how contemporaries were willing to think about crusading in terms even broader than perhaps individuals like Bernard or Eugenius III had imagined.

\section{The Texts}

As noted above, Cod. 749 consists of three distinct sections, the first two of which were copied in the same hand and speak clearly to the themes of crusade and religious violence between Christians and pagans. The texts seem to be ordered along two chronological and thematic axes. They begin with the Old Testament and the stories of Judith and Esther, then progress to more contemporary texts, including the letter of Adelgoz, the vita of emperor Henry II, and the Passio Thiemonis. At the same time, there may also have been an attempt to establish a narrative that grouped non-saints (Judith and Esther) and confessors (Henry) before the martyrs (Ignatius and Thiemo). To what extent the versified hagiographies of Gevehard were meant to be part of this program is not clear, but, as discussed further below, they could have been intended to present an alternative image of conversion that contrasted with the confrontational and violent images of the previous texts. The material relating to Rainald and the other fragmentary texts found at the end of the book can probably be explained as the result of a copyist using whatever free parchment he could find for his material in the library.

Hrabanus Maurus's commentaries on Esther and Judith were well known and circulated widely from the ninth century onwards. ${ }^{61}$ Hrabanus originally conceived the commentaries as a gift to the empress Judith in the early 830 s as consolation for the trouble and sorrow she and her husband had recently experienced. ${ }^{62}$ At the same time, Hrabanus held up the biblical queens Judith and Esther as exemplary female figures who, in their fortitude, prudence, and willingness to sacrifice themselves for their people, prefigured the ecclesia itself. ${ }^{63}$ However, these were also stories about how the ancient Israelites fought pagan enemies and overcame them using extreme violence. Both Judith and Esther thus provided medieval Christians with a rich set of metaphoric images and allegories for any struggle of the Church against its perceived enemies, both internal and external. ${ }^{64}$

61 Stegmüller, Repertorium, nos. 7038-39, printed in PL 109:539-670.

62 Mayke de Jong, "Exegesis for an Empress," in Medieval Transformations: Texts, Power, and Gifts in Context, ed. Esther Cohen and Mayke de Jong, Cultures, Beliefs and Traditions: Medieval and Early Modern Peoples 11 (Leiden, 2001), 69-100, esp. 88-89.

63 Ibid., 87-88.

64 Cf. Benzo of Alba, Ad Heinricum IV, 4.38.5, ed. H. Seyffert, MGH SS rer. Germ. 65 (Hanover, 1996), 419; Manegold von Lautenbach, Liber ad Gebhardum, chap. 44, ed. K. Franke, MGH LdL 1 (Hanover, 1891), 388; Die Briefe des Petrus Damiani, 
At the end of the Book of Esther, for example, Esther reveals Haman's plot against the Jews to her husband, king Ahasuerus, and he permits the Jews to defend themselves and destroy their persecutors. ${ }^{65}$ Hrabanus observes that "this intention of Queen Esther, by which she strived mightily to pursue and destroy her enemies, was the zeal and shrewdness of a true queen, that is, the holy church, which persecutes its enemies unceasingly, and fights to overthrow them from their foundations and subject them to herself."66 Similarly, after Judith decapitates Holofernes, she pulls down the canopy above the bed and throws the general's mutilated body onto the floor, prompting Hrabanus to observe that this was done "so that by this, soldiers of Christ ["bellatores Christi"] might be confident that they are able to easily defeat even the wickedest enemy." 67 The significance of Holofernes's defeat for later Christians was implicit, though Hrabanus seems to be casting the religious (i.e., monks or clergy) as the militant Christians in this case. A similar notion may have lain behind the inclusion of an Anglo-Saxon versification of the book on Judith contained in the London Beowulf manuscript. ${ }^{68}$ While not dealing in monsters per se, it still presents a hero(ine) overcoming a powerful foe with God's help alone, culminating in the dramatic decapitation of the dreaded general Holofernes. ${ }^{69}$

The figure of the pagan general Holofernes would have been an important one for readers thinking about crusade and its spiritual and political implications in the twelfth century as well. ${ }^{70}$ Orderic Vitalis, for example, reminded his readers when writing of Bohemund of Taranto's capture by the Danishmend Turks that even as God sometimes chastises the faithful for their sins, he will also provide the means for their liberation, just as he did with - among many other examples - Esther and Judith. ${ }^{71}$ Readers of William of Tyre's account of the death of Zengi, who was killed in his tent by a servant while passed out

ed. K. Reindel, MGH Briefe der deutschen Kaiserzeit 4, 4 vols. (Munich, 1983-93), 4: no. 153, p. 38.

65 Esther 9:11-13.

66 "Intentio haec reginae Esther, quia hostes suos valide insequi et exstirpare contendit, stadium atque solertiam verae reginae, hoc est ecclesiae, exprimit, quae hostes suos sine cessatione persequitur, et funditus prosternere atque subiicere certat." PL 109:0666D.

67 "Sicque truncum hostis corpus evolvit, cum ipsum inimicum ex omni parte infirmum et debilem esse ostendit, ut eo facilius bellatores Christi confidant hostem nequissimum se vincere posse." PL 109:0573B.

68 British Library, Cotton, Vitellius A.xv.

69 Andy Orchard, Pride and Prodigies: Studies in the Monsters of the Beowulf Manuscript (Toronto, 2003), 41. See too de Jong, "Exegesis for an Empress," 96-97.

70 For a discussion of Old Testament imagery and theology in the context of twelfthcentury Crusader chivalry, see D. H. Green, The Milstätter Exodus: A Crusading Epic (Cambridge, 1966), chap. 7 ("The Relevance of the Old Testament to the Medieval Present").

${ }^{71}$ Historia Ecclesiastica, 10.2, ed. and trans. Marjorie Chibnall, 6 vols. (Oxford, 1969), $5: 359$. 
drunk, would also no doubt have inferred the parallels between Zengi's demise and that of Holofernes. ${ }^{72}$

The story of Judith had already been translated into German verse by the early twelfth century in a rather free adaptation of the biblical book that cast the protagonist very much in the mold of an epic Romance heroine not unlike Roland. ${ }^{73}$ The only witness for the so-called Ältere Judith is a twelfth-century miscellany from the Bavarian abbey of Vorau (est. 1163) that contains a number of important Middle High German verse texts, from the Kaiserchronik to the Ezzolied and Pfaffe Lamprecht's Alexanderlied, that formed a compendium of classical and biblical history alongside works dedicated to more contemporary events. ${ }^{74}$ A copy of Otto of Freising's Deeds of Frederick Barbarossa was later bound to it. Like Cod. 749, Sammelhandschriften like Vorau, Cod. 276 illustrate how the stories of Judith and Esther served as key exegetical reference points in biblical history that helped contemporary readers place events like the Crusade in the broader context of salvation history.

The text in Cod. 749 to receive the most attention from scholars over the past century is surely the Crusade Letter of Adelgoz, or the Epistola pro auxilio adversus paganos, a unique survival in this manuscript that sheds important light on the evolution of Crusader thought in German lands in the twelfth century. ${ }^{75}$ Its inclusion here is most likely due to the fact that archbishop Frederick I of Cologne (d. 1131) was one of the letter's addressees; a copy was likely available or was circulating in the twelfth century in and around institutions in the area of Cologne with close contacts to the archiepiscopacy, and Grafschaft would certainly have been among them. The text is an encyclical letter from archbishop Adelgoz of Magdeburg (1107-19) to a number of bishops and abbots of the German kingdom, as well as to "princibus, militibus, ministerialibus, clientibus, omnibusque maioribus et minoribus," calling upon them to rise up and strike against the pagan Slavs and seize their land, just as the Frankish Crusaders had recently done in the Holy Land. Based on the known dates of several of the individuals addressed in the letter, it appears to have been composed around 1108. In

72 A History of Deeds Done Beyond the Sea, 16.7, ed. A. C. Krey and E. A. Babcock, 2 vols. (New York, 1943), 2:146.

73 Deutsche Gedichte des XI. und XII. Jahrhunderts, ed. Josef Diemer (Vienna, 1849; repr. Darmstadt, 1968), 117-23. Cf. Green, Millstätter Exodus, 236.

74 Kurt Gärtner, "Vorauer Handschrift 276," in Verfasserlexikon, 2nd ed. (Berlin and New York, 1999), 10:516-21. See also vol. 11 (2004), 1638.

75 Urkundenbuch des Hochstifts Merseburg, ed. P. F. Kehr (Magdeburg, 1937), no. 91, p. 75. See in particular Constable, "Early Crusading" (n. 31 above), 203-14, which surveys the extensive body of twentieth-century scholarship on the text. For a close analysis of the text, particularly its biblical imagery, see Marian Dygo, "Crusade and Colonization: Yet Another Response," Quaestiones medii aevi novi 6 (2001): 319-25. 
justifying his appeal to make war on the heathens, Adelgoz details the terrible crimes and oppressions suffered by Christians when they fall into pagan hands:

Some they behead and sacrifice their heads to their evil gods. Of others, after their entrails have been removed, they bind together the cutoff hands and feet, and, mocking our Christ they say: Where is their God? Some others who have been raised on a gibbet, in order to increase their suffering, they allow to prolong a life that is more miserable than any death, since while still alive they perceive their own suffering as each limb is cut off, and they are finally miserably eviscerated after the stomach is cut open. ${ }^{76}$

Part of this description echoes a passage from Adam of Bremen's History of the Archbishops of Hamburg-Bremen wherein he recounts the brutal lynching of bishop John of Mecklenburg by rebellious Slavs in the uprising of 1066, having his hands and feet cut off and his head fixed on a spear and offered as a sacrifice to the deity Redigost. ${ }^{77}$ Such images were apparently current among clerical writers for a long while along the German-Slavic frontier. Helmold of Bosau, who used Adam's text, recounts the death of John and also claims that tearing the bowels out and winding them around a stake was a favorite punishment inflicted by the pagan Slavs on their Christian victims. ${ }^{78}$

A number of scholars, most recently Giles Constable and Marian Dygo, have observed that this letter is an important witness to the development of new ways of thinking about conquest and holy war in the Middle Ages. ${ }^{79}$ The ideology of retaking and reoccupying the Holy Land was a fluid one that could be readily adapted to situations such as that on the German-Slavic frontier, and Adelgoz's letter suggests that contemporaries readily recognized the ways the First Crusade's success could resonate with other enterprises. While Adelgoz, among other inducements, holds out the prospect of taking and settling the lands of the unbelievers, he also makes it clear to his audience that they have an obligation to avenge crimes committed by the pagans against innocent Christians. Indeed, in addition to its borrowings from Adam of Bremen, the letter of Adelgoz betrays stark affinities with the speech of Urban II in Robert of Rheims's account of the First Crusade, particularly in its description of Saracen atrocities as well as in its promise of land and other material benefits for Crusaders. ${ }^{80}$ Whether, as Peter Knoch suggested, Adelgoz in fact made direct use of the Historia, or, as Marcus Bull and Damien Kempf have recently argued, they simply drew from a

76 Constable, trans., in "Early Crusading," 211-12.

77 History (n. 29 above), 3.50-51, trans. Tschan, 157-58.

78 Chronicon Sclavorum (n. 32, above), bk. 1, chap. 52, trans. Tschan, 159-60.

79 See above, n. 75.

80 Robert the Monk, Historia Iherosolymitana, ed. and trans. Carol Sweetenham, Crusade Texts in Translation 11 (Aldershot and Burlington, VT, 2005), 80. 
shared stock of rhetorical imagery or oral sources, the preservation of the letter in Cod. 749 was certainly meant to draw, in Derolez's term, associative connections between accounts of pagan violence in the present and the past. ${ }^{81}$

This underscores how images of pagan atrocities were remarkably fungible across a variety of contexts and that at least part of what motivated crusading was the desire to acquit and avenge crimes and cruelty practiced against Christians. As Daniel Baraz has observed, contrary to popular assumptions about the banal nature of medieval cruelty, gruesome torture and images of pain were discourses of otherness, designed to elicit strong emotional reactions and spur people to demand justice and vengeance against an enemy who had violated the norms of humanity. ${ }^{82}$ The compiler of Cod. 749 wished to foreground these instances of extreme cruelty, making an implicit argument about the connection between paganism, barbarism, and Christian sacrifice that brought the element of righteous vengeance within Crusade ideology into sharper focus.

Adelgoz also situates his broader argument within an exegetical framework that, as Constable noted, sought to place the "undertaking in biblical terms and in relation to biblical events brought into the present." 83 While he does not quote directly from Judith or Esther, the themes of violence and resistance to religious persecution that lay at the center of the letter's message connect profoundly with the allegorical images of the persecuted Church at the heart of Hrabanus's commentaries on the two Old Testament books. Miriam Dygo likewise has underscored the way the letter's rhetoric links the potential settlement of Slavic lands by Christians to the Israelites' taking of the Holy Land in the book of Joshua and images of the terra promisionis elsewhere in the Old Testament. ${ }^{84}$ The compiler of Cod. 749 did not include the letter along with Hrabanus's commentaries merely to reiterate or recapitulate ideas contained in them but to focus attention on what the letter left out: after the Promised Land is taken, the chosen people - the Church - still must defend itself, a notion that would have no doubt focused minds in the wake of the loss of Edessa in 1144 and perhaps more so in the decades after the inglorious conclusion of the Second Crusade.

The inclusion of the Bamberg vita of Emperor Henry II, a lay ruler and confessor, may appear at first glance to be an outlier in a collection of biblical exegesis, martyrdom, and Crusade-related material. However, when considered alongside the immediately preceding texts in the manuscript, themes of pagan violence

81 Peter Knoch, “Kreuzzug und Siedlung: Studien zum Aufruf der Magdeburger Kirche von 1108," Jahrbuch für die Geschichte Mittel-Ostdeutschlands 23 (1974):1-35; The Historia Iherosolimitana of Robert the Monk, ed. Marcus Bull and Damien Kempf (Rochester, NY and Woodbridge, UK, 2013), xxxv-xxxviii.

82 Medieval Cruelty: Changing Perceptions; Late Antiquity to the Early Modern Period (Ithaca and London, 2003), 8-10.

83 Constable, "Early Crusading," 210.

84 Dygo, "Crusade and Colonization," passim. 
and war against the Slavs found in Adelgoz's letter suddenly appear to fall into sharper relief and the associative salience of the codex's contents once again becomes evident. ${ }^{85}$ The text, based on a dossier produced in Bamberg in the mid-1140s supporting the canonization of the last Ottonian emperor, portrays Henry as a confessor insofar as he used his position to fight for the Church, particularly against the pagan Slavs and (barely Christian) Bohemian and Polish polities that threatened the borders of his kingdom. ${ }^{86}$ Early in his reign, for example, the vita tells us that he convened a diet at Quedlinburg where he decided to fight back against the "Poles, Bohemians and other Slavs in nearby regions who were laying waste to the border areas of the kingdom."87 Near Walbeck, Henry surveys the damage wrought by the barbarians and swears an oath, dedicating his victory in the coming battle to Saints Lawrence (the patron of nearby Merseburg), George, and Hadrian (See Fig. 2) ${ }^{88}$ Naturally, the barbarians are vanquished and Henry restores the diocese of Merseburg to its former glory. ${ }^{89}$ Henry embodies precisely the qualities of a Christian holy warrior that the letter of Adelgoz calls on both clerics and laymen of every status to emulate in fighting the Slavs.

Henry's canonization coincided with the launch of the Second Crusade in 1146, and some scholars have speculated that Conrad III's involvement in raising one of his predecessors to sainthood laid the groundwork for his own participation in a crusade. ${ }^{90}$ According to the author of the dossier of miracles assembled to support the case for Henry's sainthood, Conrad III made a personal appeal in the matter to Eugenius III on behalf of the cathedral of Bamberg, of which he

85 Vita sancti Heinrici regis et confessoris und ihre Bearbeitung durch den Bamberger Diakon Adelbert, ed. Marcus Stumpf, MGH SS rer. Germ. 69 (Hanover, 1999). The version in Darmstadt 749 is the so-called "Fassung I." See Renate Klauser, Der Heinrichs- und Kunigundenkult im mittelalterlichen Bistum Bamberg (Bamberg, 1957), 71-74.

86 See Stumpf, "Einleitung," in Vita Sancti Heinrici, ed. idem, 32-48; and Klauser, Heinrichs- und Kunigundenkult, 71. On Henry's legacy as leader in the Christian expansion to the east (particularly among Slavs and the Hungarians) in the context of his canonization in 1146, see Phillips, Second Crusade (n. 24 above), 92.

87 Vita Sancti Heinrici, chap. 3, ed. Stumpf, 234-35.

88 Lawrence's patronage in Merseburg was itself attributed to the battlefield oath made by Otto I at the Lechfield in 955 to create a bishopric dedicated to the Roman martyr if he defeated the Hungarians. See Vlasto, Entry of the Slavs into Christendom (n. 54 above), 147.

89 Vita Sancti Heinrici, chap. 4, ed. Stumpf, 235-39. As noted by Stumpf, "Einleitung," 36 , this episode in the vita conflates a number of campaigns against the Poles and Slavs over the course of Henry's reign into a single, epic battle described in terms not unlike a crusade. The vita passes over the fact that Henry actually fought the Poles in an alliance with the pagan Liutizi. See Hans K. Schulze, "Eine unheilige Allianz: Was die Quedlinburger Annalen zum Jahre 1003 berichten und was sie verschweigen; das Osterfest zu Quedlinburg und das Bündnis Heinrichs II. mit den heidnischen Slawen," Quedlinburger Annalen 6 (2003): 6-13. See too Klauser, Heinrichs- und Kunigundenkult, 73.

90 Phillips, Second Crusade, 228-43. 


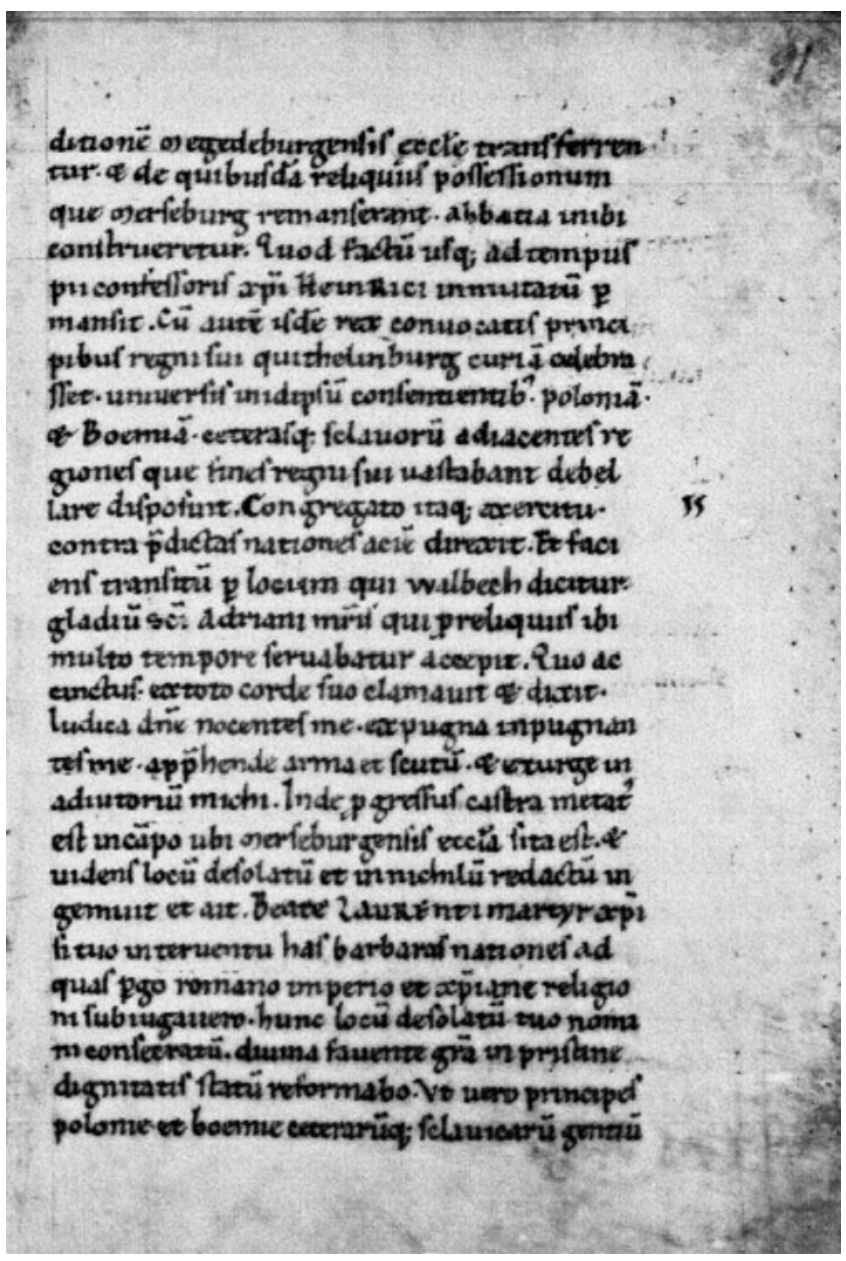

Figure 2: Darmstadt, Cod. 749, fol. 91r., ex Vita Heinrici imperatoris. The text to the left of the marginal ticks reads: Congregato itaque exercitum contra predictas nationes aciem direxit. Et faciens transitum per locum qui Walbech dicitur, gladium sancti Adriani martyris qui pro reliquis ibi multo tempore servabatur accepit.

himself, like Henry, had been an important patron. ${ }^{91}$ Elevating the status of Bamberg was probably a more immediate goal for Conrad than anything relating to the Crusade, which was then in the earliest stages of its inception. Eugenius

\footnotetext{
91 Regesta Imperii, vol. 4, 1.2 no. 342, accessed 26 March 2015, http://www.regestaimperii.de/id/1145-06-16_1_0_4_1_2_343_D342, citing Adalberti miracula s. Heinrici, MGH SS IV, 813. See too Klauser, Heinrichs- und Kunigundenkult, 51, who argues that Conrad's efforts were aimed at compensating for his failure to be crowned emperor.
} 
announced Henry's formal canonization in March 1146, shortly before Louis VII took the cross at Vezelay and well before Bernard had begun his preaching tour of the German lands. ${ }^{92}$ It was not until December of 1146 that Conrad seriously entertained the prospect of taking up the cross, but the monks of Grafschaft perhaps saw a connection between Henry's (albeit misleading) legacy as a Slavfighter and the Wendish Crusade imagined in the Letter of Adelgoz. Henry had been a Wendish Crusader avant la lettre.

The dramatic contest between Christian virtue and pagan arrogance is fundamental to early Christian martyr narratives, but few hagiographic texts foreground the Christian polemic against paganism like the Passion of Ignatius. Ignatius, bishop of Antioch, was an early Christian apologist and martyr condemned by the emperor Trajan in the early second century and distinguished by his eagerness to face the wild beasts in the Roman Coliseum. ${ }^{93}$ According to the account of his condemnation and death passed down in the later Passio, Ignatius famously defied the order of the emperor Trajan for all subjects of the empire, pagan and Christian, to offer sacrifices to the gods, and, when the emperor arrived in Antioch and heard about Ignatius's defiance, he ordered the bishop arrested. Following an inquest in which Ignatius boldly denounced the emperor's pagan beliefs, he was sentenced to die ad bestias in Rome. ${ }^{94}$

The Latin recension of the Passio Ignatii transmitted in Cod. 749, the so-called "Bollandist version," appears in a number of legendaries and martyrologies throughout France, Flanders, and the German lands from the ninth century onwards. ${ }^{95}$ Its primary feature is a series of lengthy dialogues between Ignatius and Trajan about paganism and the truth of Christianity. ${ }^{96}$ According to the Passio, following his arrival in Rome, Ignatius was summoned again by Trajan

92 JL 8882.

93 W. R. Schoedel, "Polycarp of Smyrna and Ignatius of Antioch," in Aufstieg und Niedergang der römischen Welt, 2nd series, vol. 27.1 (New York and Berlin, 1993), 272-358. The vast majority of scholarly material on Ignatius is dedicated to the theological significance of his letters, not the accounts of his martyrdom, which are of a much later date and largely fictitious.

94 BHG 813, in J. B. Lightfoot, ed. and trans., The Apostolic Fathers, vol. 3, pt. 2 (London, 1889), 477-94 (Engl. trans. 575-79).

95 Martyrium Ignatii Latinum alterum siue Bollandianum (compilatum ex Actis Antiochenis et Romanis graece conscriptis) (BHL 4256) = AA SS Feb. 1, cols. 29-33. On the manuscripts, see http://bhlms.fltr.ucl.ac.be/querysaintsection.cfm?code_bhl $=4256$, accessed 23 October 2014. This recension, the earliest witness for which dates to the ninth century, appears to be a reworking (and elaboration) of an earlier sixth-century Latin account of Ignatius's martyrdom edited by J. Mallet and A. Thibaut, Les manuscrits en écriture bénéventine de la Bibliothèque capitulaire de Bénévent, 3 vols. (Paris, 1984-97), 1:283-85; 287-90. See too the discussion by Lightfoot, ed., The Apostolic Fathers, 371-73.

96 A. Bolhuis, "Die Acta Romana des Martyriums des Ignatius Antiochenus," Vigiliae Christianae 7 (1953): 143-53. 
to appear before the Senate to defend his actions - a tableau that, of course, affords the bishop an opportunity to discourse on Christian theology and attack paganism. ${ }^{97}$ As Ignatius stubbornly refuses again and again to yield and sacrifice to the pagan gods, Trajan orders more savage tortures to be applied: that his body be raked with hooks and sharp stones; that his hands be seared with fire; that burning strips of oil-soaked papyrus be applied to his body; that he be roasted on a bed of coals, and so on. ${ }^{98}$ Finally, Trajan asks Ignatius to explain the faith that has made him able to endure such torment. But since he still will not abjure his religion, the emperor and Senate sentence Ignatius to death. Trajan nonetheless remains so impressed by the martyr's comportment that he allows Ignatius's remains to be taken away for burial and, later, in his famous correspondence with Pliny the Younger, urges the governor to deal leniently with accused Christians.

The Passio Ignatii here serves a similar function to the Vita sancti Heinrici in providing a broader ideological and historical context for Adelgoz's call to arms. The brutal torments suffered by its protagonist are not dissimilar to the atrocities attributed to the pagan Slavs, or, as shown below, suffered by archbishop Thiemo at the hands of his Saracen captors. He was also a bishop. This represents another important thematic link that connects the Passio with both the Letter of Adelgoz and the Passio Thiemonis immediately following it. Adelgoz, to be sure, was not the victim of a martyrdom, but the letter certainly underscores his initiative as an archbishop, and it was addressed primarily to the other prelates of northern Germany and imperial Francia at the time. ${ }^{99}$ It also draws the reader from a milieu focused on the Slavic frontier towards the east and the Mediterranean, specifically Ignatius's see of Antioch. Even though his martyrdom eventually takes place in Rome, Ignatius's story begins in Antioch, which remained an important Christian possession in the east during the Crusades and featured prominently in some of the earliest and most influential Crusade romances, particularly the Chanson d'Antioche. ${ }^{100}$ When the Turkish general Nur ed-Din killed prince Raymond of Antioch and threatened

97 The confrontation or debate between the martyr and pagan judge was a feature of the earliest martyr accounts, beginning with Polycarp. See Hippolyte Delehaye, Les passions des martyres et les genres littéraires, 2nd ed., Subsidia Hagiographica 13b (Brussels, 1966), 254-73, and on interrogations by the emperor personally, 245-46.

98 On various topoi of torture, see Delehaye, Les passions des martyres, 273-87. Thomas Sizgorich also drew attention to these graphic depictions of torture in his Violence and Belief in Late Antiquity: Militant Devotion in Christianity and Islam (Philadelphia, 2009), and in particular their role in forging narratives of communal history and identity. See esp. chap. 2, "The Living Voice of Kindred Blood: Narrative, Identity, and the Primordial Past."

99 Cf. Constable, "Early Crusading" (n. 31 above), 199.

100 See Carol Sweetenham, "Chanson d'Antioche," in Encyclopedia of the Medieval Chronicle, ed. Graeme Dunphy, Brill Online, s.v., accessed 12 May 2016, http://reference works.brillonline.com/entries/encyclopedia-of-the-medieval-chronicle/chanson-dantiocheEMCSIM_00433. 
the city in 1149, it led both Eugenius and Bernard to call for yet another crusade, though, perhaps unsurprisingly, without success. ${ }^{101}$

There is no evidence that these particular events spurred a sudden interest in Ignatius's cult, in this manuscript or elsewhere, but the Antiochene setting provides a nuanced, yet critical, association with the story of Thiemo, a bishop who died in Saracen captivity somewhere in either Anatolia or Egypt. While scholars have noted the resonances between Adelgoz's letter and Urban II's speech in Robert the Monk's Historia, none have yet drawn attention to the fact that they also appear in a manuscript with the Passion of Archbishop Thiemo, a Crusade-era martyr whose torture and death testified to the pagan (in this case Turkish or Saracen) penchant for cruelty. ${ }^{102}$ Archbishop Thiemo of Salzburg, a long-suffering partisan of the reform papacy in Bavaria, was one of the more prominent participants in the so-called Crusade of 1101, an ill-fated expedition led by duke Welf IV of Bavaria and the margravine Ita of Babenberg that sought to bolster the nascent Latin presence in Palestine following the surprising success of the First Crusade. ${ }^{103}$ When most of the German army was wiped out by the Seljuks in an ambush near Heraclia (Eregli) in Asia Minor, Thiemo was among those taken prisoner. Ekkehard of Aura and Albert of Aachen both devote considerable attention to this so-called "rear Crusade" and its dramatic failure but include no specific information about Thiemo's ultimate fate beyond noting that he was captured along with many others. ${ }^{104}$ By the mid-twelfth century, however, a legend had emerged in certain parts of the German kingdom that held that, following his capture, Thiemo was brutally tortured and executed when he willfully

101 Phillips, Second Crusade (n. 24 above), 269-72.

102 BHL 8132: Passio Thiemonis auct. Heinrico Abbate Breitenowensi, ed. W. Wattenbach, MGH SS XV.2, 1236-38.

103 On the Crusade of 1101, see Marshall W. Baldwin, ed., A History of the Crusades, vol. 1, The First Hundred Years, 2nd ed. (Madison, WI, 1969), 350-67; and, more recently, Jonathan Riley-Smith, The First Crusade and the Idea of Crusading (London and New York, 1986), chap. 5. On Thiemo and the various extant passion narratives, see now John Eldevik, "Thiemo of Salzburg: Violence, Sanctity, and Religious Identity in the Age of Crusade," in Christian Discourse, Distinction, and Identity, ed. Walter Pohl and Andreas Fischer, Social Cohesion, Identity and Religion in Europe 2 (Vienna, forthcoming); John V. Tolan, "The Martyrdom of Bishop Thiemo," in Muslim-Christian Relations: A Bibliographical History, ed. David Thomas and Alex Mallett, vol. 3, (1050-1200) (Leiden, 2011), 555-57. Older treatments include: K. Muth, St. Thiemo: Erzbischof von Salzburg und Kreuzfahrer, $† 28$. September, 1102 (1101) (Passau, 1896); Paul Riant, "La Legende du martyre en Orient de Thiemon, archevêque de Salzbourg (28 septembre 1102)," Revue des questions historiques 39 (1886): 218-37; and Jakob Wichner, Geschichte des Benediktiner-Stiftes Admont, 4 vols. (Admont, 1874-80), 1:50-58.

104 Ekkehard, Chronik, ed. Franz Schmale-Ott and Irene Schmale-Ott (Darmstadt, 1972), s. a. 1101, 171, 327-33 (the so-called Hiersolymita); Albert of Aachen, Historia Ierosolimitana: History of the Journey to Jerusalem, ed. and trans. Susan Edgington (Oxford, 2007), bk. 8 , chap. $34,625-27$. 
destroyed some idols belonging to the Saracen king. ${ }^{105}$ The early version in Cod. 749 is attributed to the Hessian monk Heinrich of Breitenau and claims to be based on an eyewitness account. ${ }^{106}$ It briefly notes Thiemo's career as a monk and bishop before quickly setting the scene for his martyrdom. Having been taken prisoner on his way to Jerusalem, Thiemo is asked by the Saracen king to repair the leg of a broken idol. Thiemo initially feigns compliance with the request but instead takes a hammer and destroys the broken idol along with all the others. The furious sultan orders Thiemo bound to a chair placed in front of a table, upon which soldiers then slowly sever Thiemo's hands, feet, and limbs until death ensues. Following Thiemo's death, the torturers rend their own flesh with their teeth and the sultan himself is struck with paralysis, which he realizes must be a punishment sent by the Christian God. He sends messages to two other Saracen rulers, admonishing them not to mistreat their Christian prisoners lest a similar fate befall them.

One of Thiemo's companions, an abbot of an unnamed monastery, also suffers disembowelment: his entrails are pulled out of an opening in his side and wound around a stick, a description of pagan torture virtually identical to those highlighted in the Letter of Adelgoz and Urban's speech in Robert the Monk's chronicle. ${ }^{107}$ Notably, in several other later iterations of the Passio Thiemonis from Bavaria, Thiemo is tied spread-eagle to the ground while executioners disembowel him by winding his intestines around a winch and choirs of angels bear his soul to heaven, an image that enjoyed some currency in Bavarian religious art in the latemedieval and early modern period. ${ }^{108}$

105 BHL 8132-35. Otto of Freising knew the story of Thiemo, if not any of the extant written versions specifically, and famously remarks in his world history that while Thiemo did indeed die as a martyr following the Crusade, the episode about the sultan's idols should not be taken at face value, as Islam is a monotheistic religion: "Quod ob fidem Christi passus sit [viz. Thiemo], fidelissima traditio habet, quod autem ydola comminuerit, ex hoc credere difficile est, quia constat universitatem Sarracenorum unius Dei cultricem esse, librosque leges necnon et circumcisionem recipere." Chronica sive historia de duabus civitatibus, ed. A. Hofmeister, MGH SS rer. Germ. 45 (Hanover, 1912), bk. 7, chap. 7, 317.

106 Of the author Heinrich of Breitenau himself, little is known aside from this work. See Verfasserlexikon, 2nd ed. (1981), 3:703-4, s.v. In his history of the abbey Hirsau (Chronicon ... Hirsaugensis 2:159 [Basil, 1559]), the sixteenth-century scholar Johannes Trithemius noted that a certain monk Heinrich from Hirsau became abbot of the monastery Breitenau near Kassel in 1132, where he achieved distinction as an author and scholar.

107 "Martyrizatur etiam cum ipso abbas eiusdem monachi, cuius relatu haec didici, et eius passio talis erat. Aperiebant latus eius ferro et de ventre eius viscera vel intestina extrahebant unco, donec circa sudem eadem convolverent et vacuum ventrem relinquerent." Passio Thiemonis auct. Heinrico, chap. 5, ed. Wattenbach, 1238.

108 BHL 8133-35. Cf. Lexikon der christlichen Ikonographie (Rome, 1974), 8:468. The apostatizing Viking chieftain Brodr meets a remarkably similar fate in Njal's Saga, following the Battle of Clontarf near Dublin. See Thomas D. Hill, "The Evisceration of Brodir in Brennu-Njals Saga," Traditio 37 (1981): 437-44. 
The Passio Thiemonis, as John Tolan has noted, is an important witness to the growing trend in Christian literature of the Crusade era, particularly the chansons de geste, to depict Muslims as pagan idolaters and merciless persecutors of the faithful. ${ }^{109}$ The Passio clearly drew upon a key "knowledge database" about Saracens and paganism in order to create a vivid backdrop for its protagonist's death and heighten the contradictions, as it were, between Islam and Christendom. The image of idolatrous Saracens in the context of Cod. 749, however, lies along a continuum of diabolical, pagan behavior that the book attempts to illuminate, beginning with the stories of villains like Nebuchadnezzar, who wished to be worshiped as a god himself, and culminating in the wicked cults of the Slavs described by Adelgoz. ${ }^{110}$ Thiemo and his companions died some half a century before the creation of Cod. 749, but Heinrich of Breitenau's succinct account of his passion allowed the manuscript's maker to draw stark parallels between Christianity's struggles against Islam in the Holy Land and on the Slavic frontier.

It would appear that monks of Grafschaft continued to regard Cod. 749 as a collection of texts that spoke to themes of religious violence, Christian identity, and conflict with the non-Christian Other well into the latter part of the twelfth century and perhaps into the thirteenth. The geographic scope of the religious discourse framed within the collection continued to expand. The partial text of the Miracula S. Thomae copied in a late twelfth- or early thirteenth-century hand at the end of the letter of Adelgoz in Cod. 749 is not related to the original Passio Thomae apostoli (BHL 8136) but in fact forms part of the corpus of high medieval texts that eventually coalesced into the legend of Prester John (See Fig. 3). ${ }^{111}$ It relates a story that a certain John, patriarch of the Christians in India, traveled to Rome, appeared before Pope Calixtus II (1119-24), and

109 Tolan, Saracens (n. 3 above), chap. 5. See too Barbara Rogemma, "Muslims as Crypto-Idolaters: A Theme in the Christian Portrayal of Islam in the Near East," in Christians at the Heart of Islamic Rule: Church Life and Scholarship in 'Abbasid Iraq, ed. David Thomas (Leiden, 2003), 1-18; and Jean-Pierre Martin, "Les Sarrasins, l'idolâtre et l'imaginaire de l'Antiquité des chansons de geste," in Littérature et religion: Au Moyen Age et à la Renaissance, vol. 1, ed. Jean-Claude Vallecalle and Pascale Blum-Cuny (Lyon, 1997), 27-46.

110 Cf. Judith 3:13: "praeceperat enim illi Nabuchodonosor, rex, ut omnes deos terrae exterminaret ut ipse solus diceretur Deus ab his nationibus quae potuissent Holofernis potentia subiugari."

111 The best edition and discussion of the texts relating to the Prester John myth are still Friedrich Zarncke, Der Priester Johannes, Abhandlungen der philologisch-historischen Classe der Königlichen Sächsischen Gesellschaft der Wissenschaft 17 (1879): 827-1028 (erste Abhandlung) and 19 (1883): 1-186 (zweite Abhandlung). The text in question here is the so-called "Abgekürzter Text" of the letter commonly titled De adventu patriarchae Indorum ad Urbem sub Calisto papa II, discussed by Zarncke, Priester Johannes, 1:832-43. An English translation (of the more complete text) is now available in Keagan Brewer, Prester John: The Legend and Its Sources, Crusade Texts in Translation 27 (Burlington, VT and Surrey, UK, 2015), 34-38. On the history of the Apostle Thomas generally, see Werner WilliamsKrapp, “Thomas (Apostel)," Verfasserlexikon, 3rd ed. (1995), 9: 811-12. 


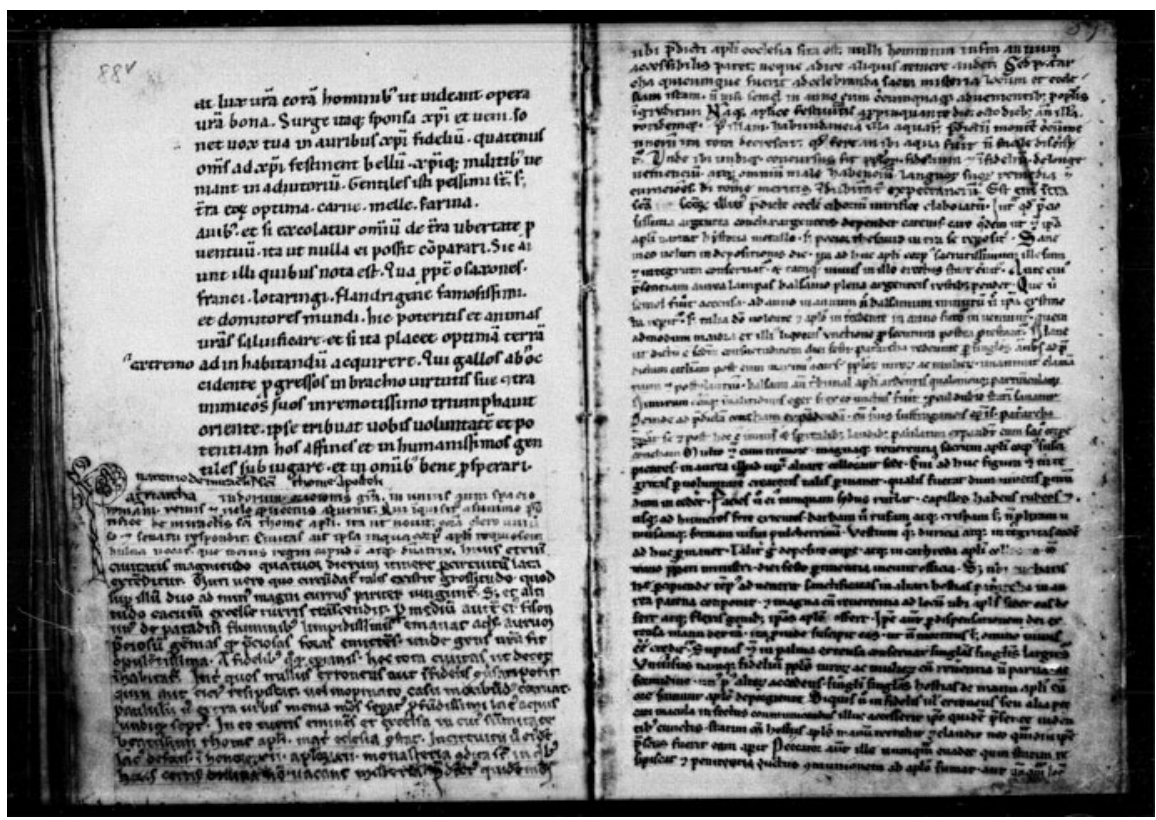

Figure 3: Darmstadt, Cod. 749, fols. 88v-89r, with the Patriarch of India's narrative about the miracles at the tomb of St. Thomas in "Hulna" appended to the Letter of Adelgoz.

proceeded to tell the assembled curia a detailed story about the wonders of his own land and in particular an extraordinary account of the miracles performed at the tomb of St. Thomas the Apostle. ${ }^{112}$ The patriarch claims that Thomas's shrine is located in a city of India named Hulna that is watered by the river Physon. Hulna is filled with an exceedingly pious Christian populace devoted to the cult of St. Thomas. No Jew or infidel dares remain in the city. On a nearby mountain, surrounded by a deep lake, is the church of St. Thomas. Once a year, as the apostle's feast day approaches, the lake miraculously dries up and the clergy and people are then able to approach the sanctuary. The body of Thomas is removed from a raft-like sarcophagus hanging in the church and placed on a magnificent throne, where he appears to be a living man. The Christian faithful then

112 Calixtus himself had been an outspoken proponent of crusade and issued a call for a new expedition to support the Latin Kingdom in the wake of the devastating Christian defeat ("Field of Blood") in Syria in 1119. See Mary Sroll, Calixtus II (1119-1124): A Pope Born to Rule (Leiden, 2004), 441-45. Anne Derbes has also noted some striking similarities between the fresco program sponsored by Calixtus in the church of S. Maria in Cosmedin in Rome and that in the church of Schwarzrheindorf undertaken by Arnold II of Cologne (n. 60 above). See "Crusading Ideology and the Frescoes of S. Maria in Cosmedin," Art Bulletin 77 (1995): 460-78. 
come to take the Eucharist directly from Thomas's hand. However, if any unabsolved sinner or heretic attempts to approach the saint surreptitiously, then his hand closes, he snatches away the host, and the intruder must immediately confess and do penance, or he dies. The pagans observing this marvel are all inspired to convert to Christianity. The Darmstadt copy goes thus far and then breaks off (at chap. 46 in the Zarnke edition). At the end of the story in the other witnesses, however, the author states that when John finished, the pope lifted his hands to heaven and gave thanks to God for the great miracles performed by St. Thomas.

The legend of the Apostle Thomas and his mission to India was well known in the medieval West, while the description of India and its wondrous features borrows from a wide range of sources, including the Alexander Romance. ${ }^{113}$ According to an early Greco-Syriac Christian tradition, later expanded and translated into Latin, following Pentecost, the Twelve Apostles each set out to preach the Gospel in a different part of the world. The region of India fell to "Doubting" Thomas. Allowing himself to be purchased as a slave craftsman to procure passage to the East, he converted many to Christianity and performed miracles before being martyred by an offended pagan king. Since at least the sixth century, Christians in the Syrian city of Edessa claimed that Thomas's remains had been brought there from India, as noted by Gregory of Tours in his Glory of the Martyrs. ${ }^{114}$ Orderic Vitalis recounted the story of Thomas as well in his Ecclesiastical History. ${ }^{115}$ Edessa was subsequently captured by the Frankish count Baldwin of Boulogne in 1098 during the First Crusade and recaptured by the Turkish emir Zengi in 1144, as noted above, sparking the Second Crusade. The relics of Thomas were later moved to the island of Chios off the coast of Asia Minor and then, in 1258, to the Italian city of Ortona in Abruzzo on the Adriatic, where they remain today.

Whatever the historicity of this "Report of Patriarch John" might be, it provides a fascinating counterpoint to the dystopian images of pagan-Christian conflict depicted in texts like the Passio Thiemonis and the Magdeburg Crusade Letter. In a land where the saints truly rule, no pagans are granted entry, and

113 Cf. K. Zelzer, ed., Die alten lateinischen Thomasakten, TU 122 (Berlin, 1977), 3-42. See too F. Wilhelm, ed., Deutsche Legenden und Legendare (Leipzig, 1907), 1-59. Bernard Hamilton, "The Lands of Prester John: Western Knowledge of Asia and Africa at the Time of the Crusades," Haskins Society Journal 15 (2006): 126-41; Richard Stoneman, "Romantic Ethnography: Central Asia and India in the Alexander Romance," The Ancient World (1994): 93-107.

114 The Glory of the Martyrs, chap. 31, trans. Raymond Van Dam (Liverpool, 1988), 51; Wilhelm, Deutsche Legenden, 43-44.

115 Historia Ecclesiastica (n. 71 above), 2.8, ed. Chibnall, 1:182-83. See Amanda Jane Hingst, The Written World: Past and Place in the Work of Orderic Vitalis (South Bend, IN, 2009), 82-83. 
the saint angrily snatches the Eucharist away from those who would receive it deceitfully. Christian unease with the Muslim Other produced texts like this that did not engage directly with Islam (or ciphers like "Saracens") but responded by envisioning spaces of expansive Christian hegemony and purity where religious alterity was safely contained or excluded. ${ }^{116}$ While Heinrich of Breitenau's Passio makes no mention of specific miracles at Thiemo's tomb, a longer, prose Passio Thiemonis (BHL 8133) from the province of Salzburg (mid- to late twelfth century) includes a remarkable anecdote that illustrates this phenomenon: on account of the numerous miracles performed at his tomb, even pagans are drawn to Thiemo's burial site. But, the Passio explains, "If any of the foreigners ["ethnici"] ever either out of presumption or to test his powers try at any time to violate the martyr's tomb, they are immediately punished either by being possessed by an evil spirit, or being struck dead." 117 There is no evidence of a direct borrowing here, but perhaps both texts were trying to make a similar point about Christian virtus in the midst of paganism and came across a similar way of expressing it: even as its parameters are more starkly delineated in these stories, the proximity of non-Christians to Christians, as in the Near East or in areas of Germany along a Slavic-pagan frontier, is perceived as a threat to Christianity. Part of what the saints do in the Miracula S. Thomae or Passio Thiemonis is first of all to emphasize the victory of Christian virtue over pagan vanity and, second, to render the non-Christian threat impotent. Thiemo smashes the idols; Henry II wipes out a pagan army; Ignatius's fearlessness and rhetorical acumen render the Roman emperor speechless and furious; Thomas's cult thrives in an opulent, far-off land where his sacred power lays unbelief low. Even after the initial portions of the manuscript were completed, later readers at Grafschaft still viewed it as the appropriate place to insert a story about St. Thomas and the Wonders of the East.

\section{The Works of Isidore of Seville and Gevehard of Grafschaft in Cod. 749}

The sections of the manuscript containing the excerpts from Isidore, the works of Gevehard, and the letters concerning Rainald of Dassel are not explicitly concerned with themes of crusade, idolatry, paganism, and martyrdom but may nonetheless contain subtle associations with the material in the rest of the manuscript that a contemporary reader would have found compelling. A selection of grammatical and philosophical definitions from Book 2 of Isidore's Etymologiae illustrates the associative logic underpinning the manuscript's organization. The

116 Christopher Taylor, "Prester John, Christian Enclosure, and the Spatial Transmission of Islamic Alterity in the Twelfth-Century West," in Contextualizing the Muslim Other in Medieval Christian Discourse, ed. Jerold C. Frakes (New York, 2011), 39-64.

117 Passio Thiemonis (BHL 8133), chap. 16, ed. Wattenbach, MGH SS 11, 62. 
excerpts from Isidore follow directly upon the commentaries of Hrabanus and in the same hand. ${ }^{118}$ Pairing exegetical works like those of Hrabanus with selections of Isidore was not unique to Cod. 749. Vienna, ÖNB, Cod. lat. 1761, for example, is a late eleventh-century compilation of grammar and exegesis (possibly from Lorsch) that includes commentaries and school texts by Hrabanus alongside a compilation of grammatical, scientific, and historical definitions from the Etymologiae. ${ }^{119}$ Medieval exegesis drew heavily on the rhetorical and grammatical arts to understand the various senses of Scripture, particularly personal and place names, as well as the broader historical and symbolic contexts of events described in the Bible. The selections from Isidore in Cod. 749 provide a conspectus of the disciplines, from rhetoric to astronomy, necessary to appreciate the allegorical or mystical sense of Scripture. ${ }^{120}$ As a segue between two exegetical texts and one grounded more clearly in a rhetorical/epistolary/homiletic tradition (the Letter of Adelgoz) on a similar topic (holy war against pagans), it makes some sense. One of Adelgoz's appeals is for monks and other religious members of society no longer to think in terms of how they represent only Mary in the Gospel story of Mary and Martha (Luke 10:38-42) but how, in the face of an unprecedented pagan threat, they needed to embrace the figure of Martha as well. ${ }^{121}$ This kind of allegorical reading of scripture, as well as the kind displayed by Hrabanus in his Old Testament commentaries, required a sound grounding in the liberal arts highlighted in the Isidorian excerpts.

The lives of Theophilus, Pelagia, and Eufrosinia were well-known tales of penitential redemption, two of which famously feature the trope of the cross-dressing female saint who passes as male. ${ }^{122}$ The three texts are rendered here into verse by the Grafschaft monk Gevehard, about whom we know little other than what

118 Isidori Hispalensis episcopi Etymologiarum sive originum libri XX, ed. W. M. Lindsay (Oxford, 1911). For identifications of the individual places in the text, see Karl Vollmöller, "Zu RF VI, 37-39," Romanische Forschungen 6 (1891): 428.

119 http://bibliotheca-laureshamensis-digital.de/view/onb_cod1761/0252, accessed 19 September 2014 .

120 On the liberal arts as tools of scriptural exegesis, see chap. 1, "Theology, Scripture and the Fourfold Sense," in Henri de Lubac, Medieval Exegesis: The Four Senses of Scripture, 3 vols. (repr. Grand Rapids, MI, 1998), 15-74.

121 Letter of Adelgoz, trans. Constable, in "Early Crusading" (n. 31 above), 213: "Most holy fathers, monks, hermits, and recluses, you have chosen the best part with Mary, but the times now require you to rise with Martha from the quiet of contemplation, since your deeply troubled brothers greatly need Mary and Martha." On the history of the Mary and Martha story in monastic literature, see Giles Constable, "The Interpretation of Mary and Martha," in Three Studies in Medieval Religious and Social Thought (Cambridge, 1995), 1143 .

122 I thank Manu Radhakrishnan for first bringing the conversion/penance theme in these legends to my attention. On these and other accounts of cross-dressing female saints, see Évelyne Patlagean, "L'histoire de la femme déguisée en moine et l'évolution de la sainteté féminine à Byzance," Studi Medievali, 3rd series, 17 (1976): 597-623. 
remains of his oeuvre in Cod. 749. ${ }^{123}$ The lives of Pelagia and Eufrosinia frequently traveled together in medieval legendaries, along with the lives of other female penitential saints in the Vitas Patrum tradition, like Thais and Marina; their inclusion here with Theophilus is perhaps idiosyncratic but unsurprising. The story of Theophilus was originally composed in Greek by a cleric named Eutychianus and translated into Latin by Paul the Deacon of Naples under the title De penitentia Theophili vicedomini. ${ }^{124}$ The work seems to have been a popular subject of versification in monastic circles: Hroswitha of Gandersheim and Marbod of Rennes both produced their own metric versions as well. ${ }^{125}$ Theophilus of Cicilia was a vicedominus who, having lost his position at a certain bishop's court, made a pact with the devil to turn out his nemesis and claim the episcopacy for himself. While this scheme initially succeeds, he soon regrets what he has done and seeks the help of the Blessed Virgin Mary to save his soul. After demonstrating his sincerity with three days and nights of fasting and penance, Mary abolishes the pact with the devil and Theophilus dies in peace. ${ }^{126}$ Pelagia of Antioch led the life of a dissolute courtesan until the preaching of the bishop Nonnus overcame the devil's power over her, whereupon she renounced her shameful profession, received baptism, and then disguised herself as a man and lived out her days as a recluse on the Mount of Olives near Jerusalem. Eufrosina (or Euphrosyne) of Alexandria was another cross-dressing saint - a young woman who wishes to escape an arranged marriage and disguises herself as a man in order to enter a monastery, where she later becomes a caregiver to her aged father.

Although they do not appear initially to deal with the same themes as the previous hagiographic texts in the codex, their position in the manuscript, as well as their historical and geographic settings, repay closer inspection. In the first place, they follow directly upon the Passio Thiemonis, which is about a saint who perishes at the hands of cruel pagans, but is also about a medieval Christian who ventured to the East with the Crusades and died somewhere in the lands of the Saracens. Thus pivoting off the conclusion the Passio Thiemonis, the reader is introduced to Theophilus of Cicilia, a native of the southeastern area of Anatolia not far from Antioch, the city where Pelagia first plied her unwholesome trade.

123 I am not aware of any single treatment of Gevehard as an author, but see Rita Beyers, "Narratio de casu Theophili uicedomini': La pénitence de Théophile dans la version de Gevehardus de Grafschaft (BHL 8124d)," in Mémoire en temps advenir: Hommage à Théo Venckeleer, ed. Alex Vanneste et al. (Leuven, Paris, and Dudley, MA, 2003), 195-216; François Dolbeau and Jean-Yves Tilliette, "Vie métrique de sainte Pélagie attribuable à Geverhardus de Grafschaft," in Pélagie la pénitente: Métamorphose d'une légende, vol. 2, La survie dans les littératures européennes, ed. Pierre Petitmengin et al. (Paris, 1984), 129-44.

124 BHL 8121.

125 BHL 8123 and 8124, respectively.

126 In the original version, Mary imposes forty days and nights' penance on Theophilus. 
Pelagia, however, who changed her name to Pelagius, eventually seeks the life of solitude on the Mount of Olives in Jerusalem:

Ierusalem venit, domini miracula vidit

Exin Pelagium cepit, perquirire clausum

Non iter ignarum, Montem scandens Olearum

Quem Christus sanxit, ascendens nobilitavit. ${ }^{127}$

The hagiographic segment of the manuscript thus concludes with Euphrosyne, a resident of Alexandria who seeks the contemplative life among the Desert Fathers. Themes of penitential piety are certainly paramount in these stories, but the association of these works in a single grouping also creates an imaginative geographic vector that draws the reader's attention to Christian roots and the Christian presence in the East and in the Holy Land. If we understand the hagiographic cluster to begin with the Vita Heinrici imperatoris, it maps a landscape of Christian/pagan conflict and conversion stretching from the Slavic frontier, across Anatolia, to Antioch, Jerusalem, and the Egyptian desert, as well as a historical horizon extending from Late Antiquity to the twelfth century. Whoever copied the excerpts from the Miracula sancti Thomae on fols. 88-89 may have done so with the intention of extending this conceptual vision still further — all the way to India.

In addition to these historical and geographical associations, the hagiographic reécritures of Gevehard also appear to bring an ideological symmetry of sorts to the images of religious conflict and violence depicted in other works within Cod. 749. Whereas the group of preceding works in the manuscript tend to foreground the possibilities of military victory or conversion by the sword, or cruel martyrdom at the hands of pagans, Gevehard's works all emphasize conversion through penance. The connection between penance and crusade is a well-established theme, of course, but these texts are not about penitential violence per se. ${ }^{128}$ Quite the contrary, they hold up as exemplary individuals who turned away from wickedness one even having sold his soul to Satan - through contrition or having heard the word of God preached. ${ }^{129}$

This contrast between the two sections may very well reflect the purposeful design of the copyist/compiler, with the Passio Thiemonis forming a kind of bridge between the themes of obdurate paganism and anti-Christian violence on the one hand and the possibilities of miraculous conversion and penitential

\footnotetext{
127 Gevehard, Vita sanctae Pelagiae, fol. 128r, lines 8-11.

128 See esp. Jonathan Riley-Smith, The First Crusaders, 1095-1131 (Cambridge, 1997), $68-70$.

129 On this theme, see Erhard Dorn, Der sündige Heilige in der Legende des Mittelalters (Munich, 1967).
} 
piety on the other hand. Specifically, the final section of Heinrich of Breitenau's Passio Thiemonis contains a brief postscript that relates how one of Thiemo's chaplains had apostatized and worshipped idols. He quickly recanted and returned to the true faith but nonetheless went to the pope in Rome, confessed what he had done, and undertook as penance to return to the place where he had denied Christ and preach the Gospel. ${ }^{130}$ Like the desperate deacon Theophilus, this chaplain "forsook God his creator and departed from God his savior" but nonetheless attempted to redeem himself with an appropriate penance. The account is somewhat ambivalent about the penitent chaplain's success as a missionary, however, noting laconically that "whether he accomplished this or not, we have not learned, because not all men accept the Word, but those to whom it is given by God." ${ }^{131}$ At this point, a reader of Cod. 749 might have recalled some of the closing words of Hrabanus's commentary on Esther: the Jews were permitted to kill so many of their enemies "because not only do those who do not want to do penance for their sins, but also those who fail to adorn their faith in the Holy Trinity with good works, show themselves worthy of perpetual death." 132

The remaining texts in Cod. 749 (fols. 136v-146v) were most likely added because of their connection either with Gevehard or archbishop Rainald of Cologne. As archbishop of Cologne, Rainald's patronage, if not actual presence, would have certainly been a significant concern for the community of monks at Grafschaft. On fol. 140r, there begins a letter from the congregation of Grafschaft to Rainald, previously provost of Hildesheim and counselor to emperor Frederick Barbarossa, congratulating him on his election as archbishop of Cologne, which occurred in May 1159. ${ }^{133}$ There is no indication of who the author may have

130 "Cuius capellanus de Christo interrogatus vivus absortus est, quia ydola est professus et reliquit Deum factorem suum et recessit a Deo salutari suo. Provocaverunt tamen illum ad penitentiam quidam fideles et ad satisfactionem concitaverunt, atque ut pro tali apostasia domnum apostolicum expeteret, persuaserunt. Quod et faciens, non aliud in peni tentiam suscepit, nisi ut quantocius reverteretur atque eo loco quo Christum negaverat libere profite retur." Passio Thiemonis auct. Heinrico (n. 102 above), chap. 5, ed. Wattenbach, 1238. It is supposedly from this contrite chaplain that the pope learns of Thiemo's martyrdom.

131 "Hoc utrum fecerit, ad nos pervenire non potuit, quia non omnes capiunt verbum istud, sed quibus datum est a Deo." Ibid. Cf. Matt. 19:11. On this point, see the remarks of Karl F. Morrison, Understanding Conversion (Charlottesville, 1992), 137-38, which offers an insightful reading of the Passio, focusing on the dramatic structure and its relationship to ideas about monastic piety and the possibility of converting pagans.

132 "Quia non solum illos qui de peccatis suis poenitentiam agere nolunt, sed etiam ipsos qui fidem sanctae Trinitatis bonis operibus adornare negligunt, dignos perpetua morte ostendit." PL 109:667A.

133 Edmond Martène and Ursin Durand, eds., Veterum scriptorium et monumentorum historicum, dogmaticorum, moralium, amplissima collection, 9 vols. (Paris, 1724-33), 1:853-56. On Rainald, see Jonathan Rotondo McCord, "Rainald of Dassel (ca. 1120-1167)," in Medieval Germany: An Encyclopedia, ed. John M. Jeep (New York, 2001), 636-37. 
been, although Gevehard would be a likely candidate, since he later wrote the Epitaphium (fols. 136v-137r) as a memorial to Rainald following his untimely death from the plague in Italy in 1167. The Epitaphium Reinaldi appears a few folios earlier in the manuscript and, because the congregation's letter is in a somewhat different, and perhaps slightly later, hand, it may have circulated separately at first before being copied into Cod. 749 in order to join it to other Gevehard/ Rainald texts. Alluding to the controversies that had already beset Rainald's career, the monks tell their newly consecrated ordinary that:

There are those who raised their hand against Christ, and tried to vilify the fame with which your heavenly Father had resolved to make your name famous; but he raised up your candle from beneath the cover of a bushel and placed it in the lantern of the church of Cologne, a most splendid ray in the firmament. ${ }^{134}$

The image of the bishop as a light raised above his church - referencing the Gospel parable in Matthew 5 - is found not only in Heinrich of Breitenau's Passio Thiemonis but in the Letter of Adelgoz as well. ${ }^{135}$ Light, of course, is a profound image in Christian discourse, and Phyllis Jestice has observed that this particular image or metaphor was popular in the literature of the tenth and eleventh centuries produced in reformist circles in Germany. ${ }^{136}$ Thus, while it is not a rare or exceptional allusion, I think it nonetheless serves as a striking thread running through not only the hagiographical material in our manuscript, but even some of the writings that at first glance seem to have been included for reasons unrelated to the main body of texts. The author (or the copyist) of the letter to Rainald was probably mindful of the uses of the lantern metaphor in other places in the manuscript and either let it inform the way he portrayed Rainald or copied it into Cod. 749 as a way of underscoring its salience in the context of Christian sacrifice. After all, though not technically a martyr, Rainald died in loyal service to the church of Cologne and the emperor.

134 "Qui levaverunt manum contra Christum, et offuscare conati sunt claritatem qua decreverat clarificare personam tui coelestis Pater tuus, sed ille tulit lucernam tuam de sub modio latebrae, et posuit super candelabrum Agrippinensis ecclesiae splendidissimum firmamenti radium." Martene and Durand, Collectio, 1:854.

135 Cf. Passio Thiemonis auct. Heinrico, chap. 1, ed. Wattenbach, 1237: "Ibi inter theoreticae disciplinae magistros tam diu sub modio humilitatis dlituit, quo adusque dextera Domini exaltus et super candelabrum Iuvavensis ecclesiae, ut luceret omnibus qui in domo fidei sunt, est positus." Letter of Adelgoz, trans. Constable (n. 31 above), 213 (quoting Matthew 5:15).

136 Dictionairre de Spiritualité, vol. 9 (Paris, 1976), cols. 1142-73, s.v. "Lumiere"; and Phyllis Jestice, "The Gorzian Reform and the Light under the Bushel," Viator 24 (1993): 51-78. 


\section{Conclusion}

In her review of Jerold Frakes's edited volume Contextualizing the Muslim Other in Medieval Christian Discourse, Sharon Kinoshita sagely cautions against reductive readings of texts that tend to settle on Christian-Muslim conflict as some essential binary in medieval thought. ${ }^{137}$ I hope to have shown that one way of complicating that binary is by examining not just texts, but whole books and their contexts, while attempting to understand the associative organization underlying what may initially appear to be random associations between the texts. In doing so, we come to see how one community of monks conceived of religious and cultural alterity not so much in terms of simple Muslim-Christian or Christian-pagan binaries but rather as a set of multi-dimensional relationships across time and space unified by salvation history and illuminated by the power of the saints.

As such, Cod. 749 does not contain a single, rigidly coherent program. Rather, the authors, readers, and copyists at Grafschaft, like Gevehard, created a dynamic work with associative points of contact between each work, whose content and context may have been amplified over time while remaining largely coherent. It is to this process of editing and compiling, however, that we have to turn in order to understand fully the production of knowledge about phenomena like the Crusade and wars against the Slavs in the Middle Ages. The principal concern of the book was Christian confrontations with the forces of religious alterity — near and abroad - created in the aftermath of the Second Crusade, but it is also about bishops and abbots and their leadership as well as the possibilities of divine mercy, spiritual reform, and conversion. These themes could be inflected in images as diverse as pagans, martyrs, crusaders, soul-selling deacons, and wonders of the East.

As members of the community of Grafschaft asked new questions about events in the world around them, they reread old texts and added new ones that allowed them to read back new meanings onto other texts in the codex. Works like the Passio Thiemonis are not simply about a particular "image" of Saracens in the Middle Ages because, even in a single work, that image is inherently unstable and only readable in dynamic relationship to the texts around it. Indeed, only one of the four extant versions of the Passio, and the only narrative version to survive in a single witness, has been discussed here, but each one could undergo a similar study along with the other texts in each manuscript witness. ${ }^{138}$

137 Sharon Kinoshita, review of Contextualizing the Muslim Other in Medieval Christian Discourse (cited in n. 116 above), in The Medieval Review (online), 12.8.11, https://scholar works.iu.edu/journals/index.php/tmr/article/view/17623/23741.

138 Cf. for example the copy of BHL 8133 found in Vorau, Cod. 277, a far more elaborate reécriture of the Passio Thiemonis produced in the diocese of Salzburg sometime in the latter half of the twelfth century. It contains a number of works of Old Testament exegesis 
Medieval readers encountered images of the East and of the religious Other in a myriad of manuscript contexts that evolved over time and could speak to a wide range of issues that sometimes had little to do with the subject matter modern readers, using individual texts in their critical editions, often attach to them. It is the intertextuality of the works themselves, as well as the witness they bear to intellectual exchange among communities of readers and writers, that should be foregrounded in any discussion of what functions a text like the Passio Thiemonis served. The questions raised by the sequence of texts that surround the various versions of Passio in its manuscripts underscore the extent to which martyrdom, crusades, Saracens, and frequently other material on Jews, the apocalypse, and wonders of the East, were things to think with as much as about and that their transmission in monastic or cathedral libraries in particular expressed a desire to understand both historical and current events within a framework of monastic spirituality, exegesis, and discipline. That is something difficult to convey in even the most expertly edited versions of these texts.

\section{Hamilton College}

Keywords: Manuscript philology, Crusades, Christian views of Islam, Scriptural exegesis, Hagiography

\footnotetext{
(particularly Jerome), as well as a number of other philosophical and hagiographical texts, including a short excerpt of the acrostic poem of the Erythraean Sybil entitled De sybilla et iudicio futuro, the Passio S. Quirini by the monk Heinrich (BHL 7032), and the story of Barlaam and Josephat, a popular tale of faith and ascetic devotion loosely based the story of the conversion of Gautama Buddha. See the full description at: http://www.vestigia.at/ vorauer_katalog/codex_277.html.
} 